\title{
Dünya Klasiklerini Blog Tasarımı Yoluyla Okuma Deneyimi -Bir Uygulama Çalışması-
}

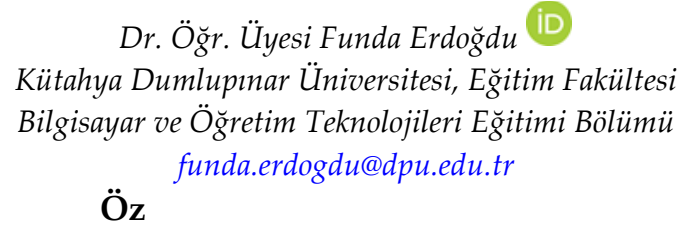

\author{
Doç.Dr. Ayşe Derya Eskimen \\ Kütahya Dumlupınar Üniversitesi, Eğitim Fakültesi \\ Türkçe ve Sosyal Bilimler Eğitimi Bölümü \\ aysederya.eskimen@dpu.edu.tr
}

$\mathrm{Bu}$ araştırma, öğretmen adaylarının bilgi ve iletişim teknolojileri (BİT) kullanımı ve eleştirel okumaya ilişkin öz yeterlilik düzeylerini belirlemeyi amaçlamaktadır. Araştırmada hem nicel hem de nitel yöntemler kullanılmıştır. Araştırma, 2018-2019 güz döneminde Dünya Edebiyatı dersini alan Türkçe Öğretmenliği Lisans Programı üçüncü sınıf öğrencilerinden toplanan veriler kullanılarak yapılmıştır. Araştırmada öğretmen adaylarından dünya edebiyatının klasiklerinden birini okumaları ve okudukları çalışma ile ilgili bir blog hazırlamaları istenmiştir. 14 hafta süren uygulama ve araştırma sonucunda öğretmen adaylarının BİT kullanımı ve eleştirel okumaya ilişkin öz yeterlik düzeyleri araştırmada kullanılan ölçeğe göre "yeterli" olarak belirlenmiştir. Nitel verilerden elde edilen bulgular ile nicel verilerden elde edilen bulguların tutarlı olduğu görülmüştür. Öğretmen adaylarının blogda yayın yapmaktan ve düşüncelerini paylaşmaktan keyif aldığ gözlemlenmiştir. Öğretmen adaylarının yazma becerilerinin blog yazma deneyimi sonrasında geliştiği görülmüştür.

Anahtar Kelimeler: Web 2.0 araçları, blog, eleştirel okuma, bilgi ve iletişim teknolojileri yeterlilik algisı.

\section{Reading Experience Through Blog Design of World Classics -An Application Study-}

\section{Abstract}

This research aims to determine the self-competence levels of pre-service teachers regarding the use of information and communication technologies (ICT) and critical reading. Both quantitative and qualitative methods were used in the research. The research was conducted using the data collected from the third-year students of the Turkish Language Teaching Undergraduate Program who took the World Literature course in the fall semester of 2018-2019. In the study, pre-service teachers were asked to read one of the classics of world literature and to prepare a blog about the study they read. As a result of the application and research that lasted for 14 weeks, teacher candidates' self-competence levels regarding ICT use and critical reading were determined as "sufficient" according to the scale used in the research. It was observed that the findings obtained from the qualitative data and the findings obtained from the quantitative data were consistent. It was observed that the pre-service teachers enjoyed publishing and sharing their thoughts on the blog. The writing skills of the preservice teachers improved after their blog preparing experience.

Keywords: Web 2.0 tools, blog, critical reading, information and communication technologies competency perception. 


\section{GİRIŞ}

Dil öğretiminde amaç, öğrencilerin temel dil becerilerini geliştirmek ve bunların en etkili şekilde kullanımını sağlamaktır. Dinleme, konuşma, okuma ve yazma olarak adlandıracağımız bu becerilerden anlamaya dayalı bir beceri olan okuma, "ses organları ve göz yoluyla algılanan işaret ve sembollerin beyin tarafından yorumlanarak değerlendirilmesi sürecidir" (Akbayır, 2013, s. 1). Kişi okuma yoluyla öğrenir, bilgiyi elde eder. Okuma yoluyla öğrendiklerini kendi bilgi ve birikim süzgeçlerinden geçirerek sorgulaması, değerlendirmesi, daha iyiyi, daha güzeli, daha doğruyu bulmaya yönelik çabalaması ise eleştirel boyutta bir okuma faaliyetidir. Bu anlamda, "eleştirel okuma, bireylerin okuduklarını, okuma yoluyla öğrendiklerini kendi bilgi ve birikim süzgeçlerinden geçirerek daha iyiyi, daha güzeli, daha doğruyu bulma çabaları; okuduklarından elde ettikleriyle daha iyi, daha güzel, daha doğru zihin ürünleri ortaya koyma faaliyetleridir" (Çifci, 2006, s. 56-57). "Eleştirel okuyucular, metinleri nesnel ve derinlemesine düşünerek okuyabilirler. Eleştirel okuma öğrencilerin metinlerle etkileşime girmesini, kitapla konuşmasını, sorular sormasını, tahmin yapmasını, eski bilgi ve deneyimleriyle bağlantı kurmasını ve önyargıları yıkmasını, gizliden ifade edileni okumasını, yeni bilgi inşa etmesini sağlayan üst bilişsel bir süreçtir" (El-Hindi, 1997; Flavell, 1993 akt. Karabay, 2012, s.81). Tanımlardan hareketle de ifade edilebilir ki, eleştirel okuma, okunan metne ilişkin bir sorgulama, metne sorular sorma ve metinle ilgili düşünme sürecidir. Millı̂ Eğitim Bakanlığ 2019 Türkçe dersi öğretim programında da öğrencilerin eleştirel bir bakış açısı geliştirmelerine yönelik "okuduklarını anlayarak eleştirel bir bakış açısıyla değerlendirmelerinin ve sorgulamalarının sağlanması" (s. 8)" beklenmiştir.

Erden'in ifade ettiği gibi “yükseköğretim kurumlarındaki öğrencilerin başarıları, ortaöğretim kurumlarındaki eğitimin niteliğine bağlıdır" (1998, s. 180). Öğretmen adaylarının eleştirel ve yaratıcı düşünme, iletişim kurma, problem çözme, araştırma, karar verme ve bilgi teknolojilerini kullanmaya yönelik tutumlarının olumlu anlamda geliştirilmesi ve teknolojiyi derslerine dâhil edebilmesi çağımızın gereğidir. Nitekim Millî Eğitim Bakanlığı tarafından 2011 yılında kabul edilen öğretmen özel alan yeterliklerinde de "öğrencilerin eleştirel ve yaratıcı düşünme, karar verme ve problem çözme becerilerini geliştirebilme" maddesine yer verilmiştir. Gelişen teknoloji ve değişen toplum yapısı, eleştirel okumayı, düşünmeyi, bilgi ve iletişim teknolojilerini (BİT) kullanmayı ve bu yönlü bir bakış açısını gerekli kılmaktadır. Bireyler okuma yazma becerisi kazandıktan sonra hızlı bir şekilde, görsel, yazıll, iletişim ve haberleşme araçları yoluyla bilgi edinme yollarına başvurmaktadır. Zira artık günümüzde kitaplardan, kütüphanelerden sonra BİT her türlü bilgiyi içinde barındıran önemli kaynaklar hâline gelmiştir.

Eğitimde dijitalleşme ve Web 2.0 araçlarının kullanımı günümüzde hızla yaygınlaşmakta, bu uygulamaların önemi her geçen gün artmaktadır. Dilin beceri alanları olan okuma, yazma, konuşma ve dinleme becerileri de bu gelişmelerden etkilenmektedir. Buna bağlı olarak okuma, dinleme, konuşma ve yazma alanlarına ilişkin dijital ortamlarda birtakım uygulamalar söz konusudur. Örneğin okuma-dinleme faaliyetleri basılı kitaplardan, e-kitaplara, sesli kitaplara, dijital metinlere yönelmiş; yazma faaliyetleri de aynı şekilde Wattpad, Wikipedia, Facebook, Twitter, Blog ve diğer ve dijital sosyal ortamlarda gerçekleşmeye başlamıştır. Yukarıda da ifade edildiği gibi dijital ortamlarda dilin okuma, dinleme, konuşma ve yazma alanlarına yönelik sesli kitap, blog, wattpad gibi uygulamalar söz konusudur. Blog "Web" ve "log" kelimelerinin birleşiminden oluşan kullanıcıların bir 
konu hakkındaki fikirlerini diğer insanların okumaları için paylaştıkları sosyal bir platformdur (Richardson, 2010). Bloglar, kullanıcılara resim, müzik ve video gibi çoklu ortam nesneleriyle yazılarını zenginleştirme olanağı da tanır (Nicolaou \& Constantinou, 2014, s. 95). Blog kullanıcıların çeşitli konular hakkında yazılar yazabilmelerine ve diğer kullanıcıların yazılara yorumlar ekleyebilmelerine olanak sağlayan Web tabanlı bir araçtır (Göktaş, 2009).

Eğitim ortamlarında öğrencilerin blog kullanımına ilişkin alan yazında yapılmış çalışmalara rastlamak mümkündür. Bu çalışmalar ağırlıklı olarak yabancı dil olarak İngilizce okuma yazma deneyimini geliştirmek amacıyla yapılmıştır. Koçoğlu (2009) tarafından bir dönem süresince 24 öğrencinin katılımıyla İngilizce yazma becerilerini geliştirecekleri blog hazırlamışlardır. Çalı̧̧manın sonunda öğrencilerin İngilizce yazma becerisinin gelişiminde blog kullanımının etkili bulunmuştur. Ruby (2011), blog kullanımının yabancı dil öğrenmede öğrencilerin kendini yansıtma ve akran geri bildirimi sayesinde yazma becerilerini geliştirdikleri sonucuna ulaşır. Noytim (2010) çalışmasında, blog kullanımının öğrencilerin yaratıc1, analitik, eleştirel düşünme becerilerini geliştirdiğini, sosyal etkileşim yaratarak okuyucu-yazar arasında etkileşim sağladığını, öğrenme motivasyonunu artırarak okuma-yazma etkinliklerinde başarıyı arttırdığı sonucunu elde etmiştir. Blogların öğrencilerin yabancı dil yazma becerisini geliştirdiği (Akdağ \& Özkan, 2017; Hui-Ju,2011); yazma becerisini geliştirmenin yanında bilişsel süreçlerine katkı sağladığı yazmaya ilişkin motive ettikleri ve eleştirel olmalarına yardımcı olduğu (Daskalogiannaki, 2012); öğretmen ve öğrencilerin blog kullanımına ilişkin olumlu tutuma sahip olduğu, yabancı dil yazma motivasyonunu artırdığı (Hsin-Yi Cyndi, 2016) görülmüştür. Blog kullanımına ilişkin olumlu gelişmelerin olduğu çok sayıda çalışma olsa da herhangi bir etkinin olmadığ çalışmalara da rastlamak mümkündür. Özdemir (2015) tarafından 40 öğrencinin katılımıyla gerçekleştirilen deneysel çalışmanın amacı blogların yabancı dil olarak öğretiminde öğrencilerin yazma becerileri ve motivasyonları üzerindeki etkisini araştırmaktır. Çalışmanın sonunda blogların öğrencilerin motivasyon ve başarısını artırmadığı ancak öğretime destek kullanımının öğretimi desteklediği vurgulanmıştır. Aydin ve Özdemir (2020) 48 öğrencinin katılımıyla gerçekleştirdiği çalışmada blog kullanarak İngilizce yazma deneyiminin kâğıt kalem kullanarak yazmaya göre öğrencileri daha fazla motive ettiği sonucunu elde etmiştir.

Bloglar öğrencilerin eleştirel düşünme ve yorumlama becerilerinin gelişimine (Noytim, 2010); etkileşimli öğrenme ortamları, yansıtıcı düşünme, bilgi işleme ve paylaşma, akran geribildirimi gibi iş birlikli etkinlikler oluşmasına katkı sağlamaktadır (Richardson, 2010). Gelişen teknoloji ve değişen toplum yapısı, eleştirel okumayı, düşünmeyi, BİT kullanmayı ve bu yönlü bir bakış açısını gerekli kılmaktadır. Günümüz ihtiyaçları göz önüne alındığında öğretmen adaylarının da diğer beceri alanlarının yanı sıra öğretmeöğrenme sürecinde teknoloji kullanımına yönelik yeterliklerini geliştirmeleri, pedagoji ve alan bilgisi içeriği ile teknolojiyi kullanma bilgi ve becerisine sahip olmaları gerekmektedir. Alan yazında yabancı dil öğretiminde blog kullanmanın okuma-yazma becerilerinin gelişimine olumlu yönde geliştirdiğine ilişkin araştırmalar yapıldığı, Türkçe okuma-yazma becerilerinin gelişimine etkisini ortaya koyan araştırmalara ihtiyaç duyulduğu saptanmıştır. Dünya edebiyatı dersi kapsamında gerçekleştirilen bu çalışmada, Türkçe öğretmen adaylarından Dünya klasiklerinden bir eseri okumaları istenmiştir. Belirlenen kriterler çerçevesinde eseri okuyup eleştirel okuma becerisi kazanmaları ve hazırladıkları blogda eseri yayımlamaları istenmiştir. Meslek hayatına başladıklarında öğrencilerine okuma, 
eleştirel okuma ve kitap sevgisini aşılayacak olan Türkçe öğretmen adayları için öğrencilerin eleştirel okuma, görsel okuma ve BíT yeterliliklerinin gelişimine katkı sağlayacak olduğu için çalışmanın önemli olduğu düşünülmektedir. Ayrıca Türkçe öğretmen adaylarının eleştirel okuma yeterlilik algıları ve eğitimde BİT kullanımına ilişkin yeterlilik algılarını blog uygulamasını kullanarak geliştirmesi öğretmen adaylarının pedagojik ve alan bilgisi gelişimine katkı sağlayacağı düşünülmektedir. Bu anlamda çalışma, öğretmen adaylarının BİT kullanımına ilişkin yeterlilik algılarının ve eleştirel okuma öz yeterlilik algılarının geliştirmesinin yanında yaratıcılık, problem çözme, eleştirel düşünme gibi 21. yüzyıl becerilerini gelişmesine de katkı sağlayacağı için önemli görülmektedir.

\section{Araştırmanın Amacı}

Bu çalışmanın amacı; okudukları kitap ile ilgili blog oluşturan Türkçe öğretmen adaylarının eleştirel okuma yeterlilik algıları ile eğitimde BİT kullanımına ilişkin yeterlilik alg1 düzeylerinin belirlenmesidir. Bu amaçla aşağıdaki sorulara cevap aranmıştır.

Blog hazırlayıp/yayımlayan Türkçe öğretmen adaylarının:

1. Eleştirel okuma öz yeterlilik algıları ne düzeydedir?

2. Eleştirel okuma öz yeterlilik algısının günlük kitap okuma süresine göre dağılımı ne düzeydedir?

3. Eleştirel okuma öz yeterlilik algısının günlük BİT kullanma süresine göre dağılımı ne düzeydedir?

4. BİT kullanmaya ilişkin yeterlilik algıları ne düzeydedir?

5. BİT kullanmaya ilişkin yeterlilik algılarının günlük BİT kullanım süresine göre dağılımı ne düzeydedir?

6. BİT kullanmaya ilişkin yeterlilik algısının günlük kitap okuma süresine göre dağılımı ne düzeydedir?

7. Blog uygulama süreci boyunca BíT'e ilişkin yeterlilik algılarınızı nasıl değerlendiriyorsunuz?

8.Okuduğunuz kitabın eleştirilerini paylaşmak için hazırladığınız blogunuzun yayımlanmasına ilişkin ne düşünüyorsunuz?

9. Kitap okuma sürecinin mi blog hazırlama/yayımlama sürecinin mi zevkli olduğunu düşünüyorsunuz?

\section{YÖNTEM}

Bu bölümde araştırmanın amacı, önemi, modeli, çalışma grubu, verilerin toplanması ve analizi hakkında bilgi verilmiştir.

\section{Araştırmanın Modeli}

Çalışmada nicel ve nitel veri toplama yöntemleri birlikte kullanılarak araştırma sonuçlarını bütünleştiren karma yöntem kullanılmıştır. Karma araştırma deseni olarak eş zamanlı çeşitleme stratejisi (concurrent triangulation strategy) kullanılmıştır. Amaç, eş zamanlı olarak toplanan nitel ve nicel verileri bir arada yorumlamak ve çeşitlemeyi sağlamaktır. Nitel ve nicel araştırma yöntemlerinin aynı araştırmada birlikte kullanılmasının amacı, nitel ve nicel araştırmaların avantajlarını artırıp dezavantajlarını ise azaltmaktır (Creswell, 2003). 


\section{Çalışma Grubu}

Araştırma Kütahya Dumlupınar Üniversitesi, Eğitim Fakültesi Türkçe Öğretmenliği bölümünde eğitim gören 47 öğretmen adayı ile gerçekleştirilmiştir.

\section{Veri Toplama Araçları}

Araştırmada nicel ve nitel veriler toplanmıştır. Nicel verilerin toplanmasında "Kişisel Bilgi Formu", "Eleştirel Okuma Öz Yeterlik Algısı Ölçeği" ve "Öğretmen Adayları için Eğitimde BİT Kullanmaya İlişkin Yeterlilik Algı Ölçeği" kullanılmıştır. Nitel verilerin toplanmasında yarı yapılandırılmış görüşme formu ve öğretmen adaylarının oluşturdukları bloglar kullanılmıştır.

\section{Nicel Veri Toplama Araçları}

Çalışmanın nicel kısmı tarama yöntemine uygun olarak tasarlanmıştır. Tarama yöntemi "görüşme veya anket yoluyla verilerin toplandığl, grubun genel görüşünü ortaya koymayı amaçlayan" yöntem (Fraenkel, Wallen \& Hyun, 2015) olarak tanımlanmaktadır.

\section{Kişisel Bilgi Formu}

Bu araştırmada Türkçe öğretmen adaylarının kişisel bilgilerini (Bilgi ve İletişim Teknolojilerini günlük kullanım süresi, ders kitabı dışında günlük kitap okuma süresi gibi) öğrenmek amacıyla kişisel bilgi formu kullanılmıştır.

\section{Eleştirel Okuma Öz Yeterlik Algısı Ölçeği}

Üniversitede öğrenim gören öğrencilerin eleştirel okuma öz yeterlik algılarını belirlemek amacıyla Karadeniz (2014) tarafından geliştirilen "Eleştirel Okuma Öz Yeterlik Algısı Ölçeği", likert tipi beşli derecelendirme ölçeğidir ve 33 maddeden oluşmaktadır. Ölçekteki maddelerin 25'i olumlu, 8'i olumsuzdur. Olumsuz maddeler tersine puanlanmıştır. Araştırma kapsamında öğretmen adaylarının demografik özelliklerini belirlemek amacı ile ölçme aracına kişisel bilgi formu eklenmiştir. Ankette yer alan seçenekler "hiç katılmıyorum", "katılmıyorum", "kararsızım”, "katılıyorum", "tamamen katılmıyorum" şeklinde sıralanmaktadır. Öğrencilerden duygu ve düşüncelerini en iyi yansıttığını düşündükleri seçeneği işaretlemeleri istenmiştir. Ölçek iki büyük şehir üniversitesinin Türk dili ve edebiyatı öğretmenliği programlarında öğrenim görmekte olan 150 öğretmen adayı tarafından cevaplandırılmıştır. Veri toplama aracında kullanılan beşli likert tipi ölçeğine uygun olarak elde edilen puanların yorumlanmasında; aralık sayısı seçenek sayısına bölünerek aralıklar belirlenmiştir $(4 / 5=0,80)$ (Kaptan, 1998). Buna yönelik olarak, ölçekte yer alan maddelerin düzeyini belirlemek için aşağıda belirtilen puan aralıkları dikkate alınmıştır: (hiç katılmıyorum 1.00 - 1.80, katılmıyorum 1.81 - 2.60, kararsızım 2.61 - 3.40, katılıyorum 3.41 - 4.20, tamamen katılıyorum 4.21 - 5.00).

Öğretmen Adaylarn için Eğitimde Bilgi ve İletişim Teknolojileri Kullanmaya İlişkin Yeterlilik Algı Ölçeğ $i$

Çalışmada kullanılan bir diğer ölçek de Şad ve Nalçacı (2015) tarafından geliştirilen Öğretmen Adaylarının Eğitimde Bilgi ve İletişim Teknolojilerini Kullanmaya İlişkin Yeterlilik Algılarını belirlemek için geliştirilen ölçektir. Ölçek formu 'oldukça yeterliyim' ile 'oldukça yetersizim' seçenekleri arasında değişen 5'li derecelendirmeli likert formatta düzenlenmiştir. Ölçek 30 maddeden oluşmaktadır. Ölçekte yer alan maddelerin düzeyini belirlemek için aşağıda belirtilen puan aralıkları dikkate alınmıştır: (hiç katılmıyorum 1.00 - 
1.80, katılmiyorum 1.81 - 2.60, kararsızım 2.61 - 3.40, katıliyorum 3.41 - 4.20, tamamen katılıyorum 4.21 - 5.00). Ölçeğin Cronbach Alpha katsayısı, 962 olarak bulunmuştur.

\section{Nitel Veri Toplama Araçları}

\section{Yarı Yapılandırılmış Görüşme Formu}

Araştırmanın nitel boyutu kapsamında öğretmen adaylarının eleştirel okuma öz yeterlilik algıları ve eğitimde BİT kullanmaya ilişkin yeterlilik algılarına ilişkin ne hissettiklerini belirlemek için araştırmacılar tarafından üç adet açık uçlu sorudan oluşan yarı yapılandırılmış görüşme formu hazırlanmıştır. Bu soruların iç geçerliğini sağlamak için doktorasını Eğitim Teknolojileri alanında tamamlamış iki alan uzmanının görüşü alınmıştır.

Öğrencilere sorulan yarı yapılandırılmış görüşme soruları şunlardır:

1. Blog hazırlama deneyimi öncesinde ve hazırlama süresince BİT'e ilişkin yeterlilik algılarınızı nasıl değerlendiriyorsunuz?

2. Okuduğunuz kitabın eleştirilerini paylaşmak için hazırladığınız blogunuzun yayımlanmasına ilişkin ne düşünüyorsunuz?

3. Kitap okuma sürecinin mi blog hazırlama/yayımlama sürecinin mi zevkli olduğunu düşünüyorsunuz?

Yarı yapılandırılmış görüşme formunda yer alan açı uçlu soruya verilen yanıtlar iki araştırmacı tarafından incelenerek veri setinin benzerlik oranı hesaplanmıştır. Bu benzerlik oranı nitel araştırmanın güvenirliğini belirlemektedir. Miles ve Huberman (1994) modelinde önerdiği güvenirlik formülü kullanılmıştır. İçsel tutarlılık olarak adlandırılan ve kodlayıcılar arasındaki görüş birliği olarak kavramsallaştırılan bu benzerlik: Güvenirlik = Görüş Birliği / (Görüş Birliği + Görüş Ayrılığı). Araştırmacılar tarafından "görüş birliğii" ve "görüş ayrıllğı" olan konular tartışılmış ve gerekli düzenlemeler yapılmıştır (Baltacı, 2017). Hesaplama sonucunda araştırmanın güvenirliği ilk soru için 90, ikinci soru için 86 , üçüncü soru için .94 olarak bulunmuştur. İçsel tutarlılığ veren kodlama denetimine göre kodlayıcılar arası görüş birliğinin en az \%80 olması beklenmektedir. Elde edilen sonuç, araştırma için güvenilir kabul edilmiştir.

\section{Blog Tasarımı ve Planlama}

Öğretmen adaylarının teknik bilgi gerektirmeden kolay kullanabilecekleri, mobil cihazlara uyumluluğu, zengin tema ve depolama alanı desteği, ücretsiz olması gibi avantajları nedeniyle yaygın kullanılan blog servis sağlayıcılarından Blogger altyapısı tercih edilmiştir. Çalışma, uygulama öncesi, uygulama sırası ve uygulama sonrası olmak üzere aşamalandırılmıştır. Dünya edebiyatı klasiklerinin öğretim malzemesi olarak kullanıldığı çalışmanın uygulama öncesi sürecinde, öğrencilere dünya klasiklerinden birer örnek eser verilmiştir. Bu eserlerden bazıları Milli Eğitim Bakanlığınca (ortaöğretim) tavsiye edilen 100 temel eser içerisinde yer almaktadır. Eserlerden hareketle oluşturulan bloglarda, eleştirel okumanın gerektirdiği doğrultuda eserin yazılış amacını sorgulama, olay, mekân ve kişiler arasındaki ilişkiyi sorgulama, yazarın bakış açısını belirleyebilme, metnindeki olay örgüsünün gelişimini tahmin edebilme, olaylar ve kavramlar arasındaki neden-sonuç ilişkisini bulabilme vd. hususlara yönelik okuma yapmaları beklenmiştir. Uygulama sürecinde, bu basamakların her birine yönelik haftalık blog etkinliklerinin oluşturulması istenmiştir. Bu süreçte aynı eseri okuduğu arkadaşıyla da iletişim hâlinde olması ve fikir alışverişi yapması beklenmiştir. Oluşturulan blogların ardından her bir öğretmen adayının 
diğer blogları da gözden geçirmesi istenmiştir. $\mathrm{Bu}$ sayede, klasik eserlerin değerlendirilmesinin, klasik tahlil metotlarından uzaklaşarak bilgisayar teknolojisi işe koşularak dersin öğrenme çıktılarına uygun, ilgi çekici ve uygun şekilde oluşturulması denenmiş ve etkin bir öğrenme ortamının tasarlanması hedeflenmiştir. Bir ders dönemi süresince haftalık yapılan uygulamalar aşağıda belirtilmiştir.

1.Hafta (24.09.2018) Öğretmen adayları çalışmanın içeriği ile ilgili bilgilendirilmiştir. Dünya Edebiyatı yazarları tanıtılmıştır.

2.Hafta (01.10.2018) Dünya klasikleri eserlerine, dönem özelliklerine değinilmiştir.

3.Hafta (08.10.2018) Öğretmen adaylarının okuyacakları kitaplar belirlenmiştir. Kitaplar okunurken hangi kriterleri dikkate alacakları belirtilmiştir. İlerleyen süreçte öğrencilere rehberlik yapılmış; oluşturulan bloglarda yapılandırılan içerikler konu, tema, kişiler (zihinsel, psikolojik, fiziksel özellikler), kişiler arası ilişkiler, arka plan, zihniyet, zaman, mekân unsurlarından hareketle ele alınması yoluyla oluşturulmuştur.

4.Hafta (15.10.2018) Bilgisayar ve Öğretim Teknolojileri alan uzmanı tarafından 'Blog' içerikli sunum yapılmıştır. Sunumda blog nedir? Blog örnekleri, blog nasıl hazırlanır?, Yeni bir blog hesabı açma, blogda yayın oluşturma, resim ekleme, video ekleme, bağlantı oluşturma, yorum yapmaya yönelik bilgiler sunulmuştur.

5.Hafta (22.10.2018) Öğretmen adayları blog hesaplarını oluşturmuşlardır. blogda yayın yapmaya başlamışlardır.

6.Hafta (29.10.2018) Öğretmen adayları sorumlu oldukları kitaba yönelik değerlendirmeler yapmışlardır. Kitaba yönelik düşünceler, yorumlar takip edilmiş; ele alınan esere yaklaşım hususunda rehberlik edilmiştir. Okunan ve değerlendirilen her bir bölümün paylaşımının gerçekleştirilmesi sağlanmıştır.

7. Hafta (05.11.2018) Öğretmen adayları okudukları kitaplara yönelik belli başlıklar altında blog yayınlarını geliştirmişlerdir. Aynı eser iki öğrenciye verilmiş bu süreçte öğrencilerin birbirleriyle fikir alışverişi yapmaları sağlanmıştır.

8-9.Hafta (12-19.11.2018) Öğretmen adayları ve öğretim elemanları hazırlanan blogları takip etmiştir. Çalışmalarında kullanacakları bilgi kaynaklarına ve bunların gösterimine ilişkin bilgi verilmiştir.

10-11.Hafta (26.11-03.12.2018) Ele alınan kitaba yönelik olarak eserin yazılış amacını sorgulama, olay, mekân ve kişiler arasındaki ilişkiyi sorgulama, yazarın bakış açısını belirleyebilme, metnindeki olay örgüsünün gelişimini tahmin edebilme, olaylar ve kavramlar arasındaki neden-sonuç ilişkisini bulabilme hususları tespit edilmiş buna yönelik gerekli rehberlik sağlanmıştır.

12-13.Hafta (10-17.11.2018) Öğrencilerin arkadaşlarının bloglarını da takip etmeleri ve beğendikleri bloglara yorum yapmaları beklenmiş ve bu anlamda onlara rehberlik edilmiştir.

14.Hafta: (24.11.2018) Öğretmen adayları blog çalışmaları incelenmiş ve değerlendirilmiştir.

\section{Verilerin analizi}

Araştırmada elde edilen nicel veriler, Türkçe öğretmen adaylarının eleştirel okuma öz yeterlilik alg1 ve eğitimde BİT kullanmaya ilişkin yeterlilik algı düzeylerinin tespit edilmesi 
amacıyla betimsel istatistikler (aritmetik ortalama ve standart sapma) hesaplanmıştır. Nicel verilerin analizinde gruplar arasında ortaya çıkan farkın anlamlı olup olmadığını, anlamlı ise anlamlı farkın hangi gruplar arasında olduğunu belirlemek üzere tek yönlü varyans analizi (ANOVA) ve Tukey testi yapılmıştır. Nitel verilerin çözümlenmesinde içerik analizi tekniği kullanılmıştır. İçerik analizi ile veriler tanımlanmaya, verilerin içinde saklı olabilecek gerçekler ortaya çıkarılmaya çalışılır. İçerik analizinde temel yapılan işlem, birbirine benzeyen verileri belirli kavramlar ve temalar çerçevesinde bir araya getirmek ve bunları düzenleyerek yorumlamaktır (Yıldırım ve Şimşek, 2006). Çalışmada kullanılan nitel veriler yarı yapılandırılmış görüşme formu ve öğretmen adayları tarafından hazırlanan bloglardan elde edilmiştir.

$\mathrm{Bu}$ araştırmada karma araştırma deseni olarak eş zamanlı çeşitleme stratejisi (concurrent triangulation strategy) kullanılmıştır; amaç, eş zamanlı olarak toplanan nitel ve nicel verileri bir arada yorumlamak ve çeşitlemeyi sağlamaktır (Creswell, 2003).

Öğretmen adaylarının 14 haftalık süreçte hazırladıkları bloglarda eleştirel okuma öz yeterlilik algısı ölçeği alt faktörlerinde yer alan Sorgulama, Çıkarımda Bulunma, Analiz, Değerlendirme, Benzerlikleri ve Farklılıkları Bulma şeklindeki beş alt faktörlere yer verilip verilmediğine göre değerlendirilmiştir.

Sayısal değişkenlerin normal dağılıp dağılmadığı Kolmogrov Smirnov ve ShapiroWilk testi ile kontrol edilmiştir.

\section{BULGULAR}

Bu bölümde öğretmen adaylarının eleştirel okuma öz yeterlilik alg1 ve eğitimde BİT kullanmaya ilişkin yeterlilik algılarının ne düzeyde olduğuna ilişkin bulgulara yer verilmiştir.

\section{Nicel Verilere İlişkin Bulgular}

Araştırmaya katılan öğretmen adaylarına ilişkin betimsel istatistikler Tablo 1'de görülmektedir.

Tablo 1. Bilgi ve İletişim Teknolojilerini (Masaüstü bilgisayar, dizüstü bilgisayar, akıllı telefon, tablet) günlük kullanım süresi

\begin{tabular}{lcc}
\hline Süre & $\mathrm{n}$ & $\%$ \\
\hline 1 saatten az & 1 & 2,1 \\
1-2 saat & 18 & 38,3 \\
2-3 saat & 24 & 51,1 \\
3-4 saat ve fazla & 4 & 8,5 \\
\hline
\end{tabular}

Öğretmen adaylarının \%38,3'ü 1-2 saat, $\% 51,1^{\prime}$ i; 2-3 saat ve $\% 8,5^{\prime}$ i 3-4 saat BiंT kullanım süresi ifade etmişlerdir.

Tablo 2. Ders Kitabı Dışında Günlük Kitap (Hikâye, Roman) Okuma Süresi

\begin{tabular}{lcc}
\hline Süre & $\mathrm{N}$ & $\%$ \\
\hline 1 saatten az & 14 & 29,8 \\
1-2 saat & 24 & 51,1 \\
2-3 saat ve fazla & 9 & 19,1 \\
\hline
\end{tabular}


Öğretmen adaylarının \%29,38'i 1 saatten az, \%51,1'i 1-2 saat ve \%19,1'i 2-3 saat ders kitabı dışında günlük kitap okuma süresi belirtmişlerdir.

Tablo 3. Eğitimde BİT Kullanmaya İlişkin Yeterlilik Algı ve Eleştirel Okuma Öz Yeterlilik Algı Ölçeği Toplam Puanlarına İlişkin Normal Dağılımın Değerleri

\begin{tabular}{lccc}
\hline & \multicolumn{3}{c}{ Kolmogorov-Smirnov } \\
\cline { 2 - 4 } & Statistic & $\mathrm{sd}$ & $\mathrm{p}$ \\
\hline BİT Yeterlilik Alg1 Toplam & .111 & 47 & .196 \\
\hline Eleştirel Okuma Toplam & .118 & 47 & .0100 \\
\hline
\end{tabular}

Tablo 3 incelendiğinde p değerinin .05 'tenen büyük olduğu görülmektedir. Bu sonuca göre veriler normal dağılım gösterdiği için analizde parametrik testler uygulanmıştır.

Araştırmanın ilk alt problemi olan 1- "Blog uygulaması kullanan öğretmen adaylarının eleştirel okuma öz yeterlilik algıları ne düzeydedir?" sorusunu cevaplamak için öğretmen adaylarının ölçekten aldıkları toplam puan hesaplanmış ve öğretmen adaylarının ölçekten aldıkları toplam puanların ortalaması, standart sapması, minimum ve maksimum değerleri hesaplanmıştır. İlgili sonuçlar Tablo 4 'te gösterilmiştir.

Tablo 4. Öğretmen Adaylarının Eleştirel Okuma Öz Yeterlilik Algısı Ölçeği Puanlarına Ait Betimsel İstatistikler

\begin{tabular}{llllll}
\hline & & En düşük puan & En yüksek puan & $\overline{\mathbf{x}}$ & Ss \\
& $\mathrm{N}$ & & & & \\
\hline Eleştirel okuma toplam puan & 47 & 106 & 156 & 126.46 & .96 \\
\hline
\end{tabular}

Tablo 4'teki sonuçlara göre öğretmen adaylarının eleştirel okuma öz yeterlilik algısı ölçeğinden aldıkları puan ortalaması 126.40, standart sapması 8.96, en yüksek puanı 156, en düşük puanı 106'dir. Öğretmen adaylarının eleştirel okuma öz yeterlilik algıları "iyi" düzeydedir.

Tablo 5. Öğretmen Adaylarının Eleştirel Okuma Öz Yeterlilik Algıları Ölçeği Alt Faktör Puanlarına Ait Betimsel İstatistikler

\begin{tabular}{llllll}
\hline & N & $\begin{array}{l}\text { En düşük } \\
\text { puan }\end{array}$ & $\begin{array}{l}\text { En yüksek } \\
\text { puan }\end{array}$ & $\overline{\mathbf{x}}$ & Ss \\
\hline Sorgulama & 47 & 33 & 50 & 39.89 & 2.98 \\
Çıkarımda Bulunma & 47 & 15 & 25 & 19.46 & 2.07 \\
Analiz & 47 & 15 & 30 & 24.17 & 2.42 \\
Değerlendirme & 47 & 18 & 26 & 22.23 & 1.40 \\
Benzerlikleri ve Farkl1lıkları & 47 & 13 & 25 & 20.42 & 2.15 \\
Bulma & & & & & \\
\hline
\end{tabular}

Öğretmen adaylarının eleştirel okuma öz yeterlilik algıları ölçeği alt faktörleri sorgulama boyutu ait aritmetik ortalama 39.89, çıkarımda bulunma 19.46, analiz 24.17, değerlendirme 22.23, benzerlik ve farklılıkları bulma 20.42 olarak bulunmuştur. 
Araştırmanın ikinci alt problemi olan "Blog uygulaması kullanan öğretmen adaylarının eleştirel okuma öz yeterlilik algısının günlük kitap okuma süresine göre dağılımı ne düzeydedir?" İlgili sonuçlar Tablo 6'da gösterilmiştir.

Tablo 6. Öğretmen Adaylarının Eleştirel Okuma Öz Yeterlilik Algısı Ölçme Aracından Aldıkları Puanların Günlük Kitap Okuma Süresine Göre Dağılımı

\begin{tabular}{|c|c|c|c|c|c|}
\hline $\begin{array}{l}\text { Günlük kitap } \\
\text { okuma süresi }\end{array}$ & $\mathrm{N}$ & $\begin{array}{l}\text { En düşük } \\
\text { puan }\end{array}$ & $\begin{array}{l}\text { En yüksek } \\
\text { puan }\end{array}$ & $\overline{\mathbf{x}}$ & Ss \\
\hline 1 saatten az & 14 & 115 & 146 & 124.57 & $.63^{7}$ \\
\hline 1-2 saat & 24 & 106 & 142 & 124.75 & $.06^{8}$ \\
\hline 2-3 saat ve fazla & 9 & 116 & 152 & 133.66 & $0.30^{1}$ \\
\hline
\end{tabular}

Tablo 6'ya göre günlük günlük 2-3 saat ve fazla kitap okuyan öğretmen adaylarının eleştirel okuma öz yeterlilik algısı ölçeğinden aldıkları puanların ortalaması 133.66'dır. Sonuçlar Tablo 7'de verilmiştir.

Tablo 7. Öğretmen Adaylarının Eleştirel Okuma Öz Yeterlilik Algısı Ölçme Aracından Aldıkları Puanların Günlük Kitap Okuma Süresine Göre Tek Yönlü Varyans Analizi Sonuçları

\begin{tabular}{lcccccc}
\hline $\begin{array}{l}\text { Varyansin } \\
\text { kaynağ1 }\end{array}$ & $\begin{array}{c}\text { Kareler } \\
\text { toplamı }\end{array}$ & Sd & $\begin{array}{c}\text { Kareler } \\
\text { ortalaması }\end{array}$ & F & p & Anlamlı Fark \\
\hline Gruplar aras1 & 587,39 & 2 & 293,69 & 4,16 &, 02 & $\begin{array}{c}\text { 1 saatten az-2-3 saat } \\
\text { ve fazla, 1-2 saat-2-3 } \\
\text { saat ve fazla }\end{array}$ \\
\hline Gruplar içi & 3101,92 & 44 & 70,49 & & & \\
\hline Toplam & 3689,31 & 46 & & & & \\
\hline
\end{tabular}

Tablo 7 günlük kitap okuma süresine göre öğretmen adaylarının eleştirel okuma öz yeterlilik algı ölçeğinden aldıkları puanlar arasında istatistiksel olarak anlamlı fark olduğunu göstermektedir $[\mathrm{F}(2-44)=4.16, \mathrm{P}<0.05]$. Görülen bu farklılığın hangi gruplar arasında olduğunu belirlemek için gruplar birbiriyle karşılaştırılmıştır. Tukey testi sonuçlarına göre; günde 1 saatten az kitap okuyan öğretmen adayları $X=124.57$ ile 2-3 saat ve fazla kitap okuyan öğretmen adayları $X=133.66$ arasında 2-3 saat ve fazla kitap okuyanlar lehine; günde 1-2 saat kitap okuyan öğretmen adayları $X=124.75$ ile 2-3 saat ve fazla kitap okuyan öğretmen adayları $X=133.66$ arasında $2-3$ saat ve fazla kitap okuyanlar lehine anlamlı farklılıklar olduğu anlaşılmaktadır.

Araştırmanın üçüncü alt problemi olan "Blog uygulaması kullanan öğretmen adaylarının eleştirel okuma öz yeterlilik algısının günlük BİT kullanım süresine göre dağılımı ne düzeydedir?" sorusuna ilişkin ilgili sonuçlar Tablo 8'de gösterilmiştir. 
Tablo 8. Öğretmen Adaylarının Eleştirel Okuma Öz Yeterlilik Algısı Ölçme Aracından Aldıkları Puanların Günlük BİT Kullanım Süresine Göre Dağılımı

\begin{tabular}{lccccc}
\hline $\begin{array}{l}\text { BİT günlük } \\
\text { kullanım süresi }\end{array}$ & $\mathrm{N}$ & $\begin{array}{c}\text { En düşük } \\
\text { puan }\end{array}$ & $\begin{array}{c}\text { En yüksek } \\
\text { puan }\end{array}$ & $\overline{\mathbf{x}}$ & Ss \\
\hline 1-2 saat & 18 & 109 & 146 & 128.05 & 8.70 \\
\hline 2-3 saat & 24 & 106 & 137 & 124.12 & 7.62 \\
\hline 3-4 saat ve fazla & 4 & 123 & 156 & 132.50 & 7.85 \\
\hline
\end{tabular}

Tablo 8'e göre günlük 1-2 saat BİT kullanan öğretmen adaylarının eleştirel okuma öz yeterlilik algısı ölçeğinden aldıkları puanların ortalaması 126.40; günlük 2-3 saat BİT kullanan öğretmen adaylarının eleştirel okuma öz yeterlilik algısı ölçeğinden aldıkları puanların ortalaması 124.12; günlük 3-4 saat ve fazla BİT kullanan öğretmen adaylarının eleştirel okuma öz yeterlilik algısı ölçeğinden aldıkları puanların ortalaması 132.50'dir. Varyans analizi ve çoklu karşılaştırmalar için yapılan Tukey testi sonuçları, günlük BİT kullanım süresine göre eleştirel okuma öz yeterlilik algısı ölçme aracından aldıkları puanların ortalamaları arasında istatistiksel olarak anlamlı bir fark olmadığını göstermektedir $\mathrm{F}(3,43)=1,37, \mathrm{p}>0.5)$.

Araştırmanın dördüncü alt problemi olan "Blog uygulaması kullanan öğretmen adaylarının BİT kullanmaya ilişkin yeterlilik algıları ne düzeydedir?" sorusunu cevaplamak için öğretmen adaylarının ölçekten aldıkları toplam puan hesaplanmış ve betimsel istatistikler hesaplanmıştır. İlgili sonuçlar Tablo 9'da gösterilmiştir.

Tablo 9. Öğretmen Adaylarının BİT Kullanmaya İlişkin Yeterlilik Algı Puanlarına Ait Aritmetik Ortalama, Standart Sapma Ve Minimum Ve Maksimum Değerleri

\begin{tabular}{llllll}
\hline & $\mathbf{N}$ & $\begin{array}{l}\text { En düşük } \\
\text { puan }\end{array}$ & $\begin{array}{l}\text { En yüksek } \\
\text { puan }\end{array}$ & $\overline{\mathbf{X}}$ & Ss \\
\hline $\begin{array}{l}\text { BİT Yeterlilik Alg1 } \\
\text { Puanlar1 }\end{array}$ & 47 & 79 & 149 & 114.53 & 16.17 \\
\hline
\end{tabular}

Tablo 9'da öğretmen adaylarının eğitimde BİT kullanmaya yönelik yeterlilik algı puan ortalaması 114.53, standart sapması 16.17, en yüksek puanı 149, en düşük algı puanı 47' dir. Öğretmen adaylarının eğitimde BİT kullanmaya ilişkin yeterlilik algıları "iyi" düzeydedir. $\mathrm{Bu}$ bulgu, öğretmen adaylarının BİT kullanmaya ilişkin yeterlilik algılarının iyi düzeyde olduğunu göstermektedir. Buna bağlı olarak ölçeğin genelinden alınan puanların ortalaması "Yeterliyim" aralığına denk gelmektedir. Bu bulgudan hareketle öğretmen adaylarının eğitimde BİT kullanmaya ilişkin algı düzeylerinin yeterli olduğu söylenebilir.

Araştırmanın beşinci alt problemi olan "Blog uygulaması kullanan öğretmen adaylarının BİT kullanmaya ilişkin yeterlilik algılarının günlük BİT kullanım süresine göre dağılımı ne düzeydedir?" İlgili sonuçlar Tablo 10’da gösterilmiştir. 
Tablo 10. Öğretmen Adaylarının Eğitimde BİT Kullanmaya İlişkin Yeterlilik Alg1 Ölçme Aracından Aldıkları Puanların Günlük BİT Kullanım Süresine Göre Dağılımı

\begin{tabular}{llcccc}
\hline $\begin{array}{l}\text { BİT günlük } \\
\text { kullanım } \\
\text { süresi }\end{array}$ & $\mathbf{N}$ & $\begin{array}{l}\text { En düşük } \\
\text { puan }\end{array}$ & $\begin{array}{l}\text { En yüksek } \\
\text { puan }\end{array}$ & $\mathbf{\mathbf { X }}$ & Ss \\
\hline $\begin{array}{l}1-2 \text { saat } \\
\text { 2-3 saat }\end{array}$ & 18 & 83 & 149 & 115.16 & 15.43 \\
\hline $\begin{array}{l}3-4 \text { saat ve } \\
\text { fazla }\end{array}$ & 4 & 79 & 147 & 113.75 & 15.43 \\
\hline
\end{tabular}

Tablo 10'a göre günlük 3-4 saat ve fazla BİT kullanan öğretmen adaylarının BİT kullanmaya ilişkin yeterlilik algı ölçeğinden aldıkları puanların ortalaması 124.50'dir. Günlük BİT kullanım süresine göre BİT yeterlilik algı ölçme aracından aldıkları puanların ortalamaları arasında istatistiksel olarak anlamlı bir fark olmadı̆̆ını göstermektedir $\mathrm{F}(3,43)=2, \mathrm{p}>0.5)$.

Araştırmanın altıncı alt problemi olan "Blog uygulaması kullanan öğretmen adaylarının BİT kullanmaya ilişkin yeterlilik algısının günlük kitap okuma süresine göre dağılımı ne düzeydedir?" İlgili sonuçlar Tablo 11'de gösterilmiştir.

Tablo 11. Öğretmen Adaylarının BİT Kullanmaya İlişkin Yeterlilik Alg1 Ölçme Aracından Aldıkları Puanların Günlük Kitap Okuma Süresine Göre Dağılımı

\begin{tabular}{|c|c|c|c|c|c|}
\hline $\begin{array}{l}\text { Günlük kitap } \\
\text { okuma süresi }\end{array}$ & $\mathbf{N}$ & $\begin{array}{l}\text { En düşük } \\
\text { puan }\end{array}$ & $\begin{array}{l}\text { En yüksek } \\
\text { puan }\end{array}$ & $\overline{\mathbf{X}}$ & Ss \\
\hline 1 saatten az & 14 & 91 & 149 & 110.42 & 14.36 \\
\hline 1-2 saat & 24 & 79 & 147 & 112.08 & 16.72 \\
\hline $\begin{array}{l}2-3 \text { saat ve } \\
\text { fazla }\end{array}$ & 9 & 111 & 148 & 127.44 & 11.40 \\
\hline
\end{tabular}

Tablo 11'e günlük 2-3 saat ve fazla kitap okuyan öğretmen adaylarının BİT kullanmaya ilişkin yeterlilik algı ölçeğinden aldıkları puanların ortalaması 127.44'dür. Sonuçlar Tablo 12' de verilmiştir.

Tablo 12. Öğretmen adaylarının BİT kullanmaya ilişkin yeterlilik algı ölçme aracından aldıkları puanların günlük kitap okuma süresine göre tek yönlü varyans analizi sonuçları

\begin{tabular}{|c|c|c|c|c|c|c|}
\hline $\begin{array}{l}\text { Varyansın } \\
\text { kaynağı }\end{array}$ & $\begin{array}{l}\text { Kareler } \\
\text { toplamı }\end{array}$ & Sd & $\begin{array}{l}\text { Kareler } \\
\text { ortalaması }\end{array}$ & $\mathbf{F}$ & $\mathbf{p}$ & Anlamlı Fark \\
\hline Gruplar arası & 1880,21 & 2 & 940,10 & 4,07 & .02 & $\begin{array}{l}1 \text { saatten az-2-3 saat } \\
\text { ve fazla, } 1-2 \text { saat- } 2-3 \\
\text { saat ve fazla }\end{array}$ \\
\hline Gruplar içi & 10157,48 & 444 & 230,85 & & & \\
\hline Toplam & 12037,70 & 446 & & & & \\
\hline
\end{tabular}

Tablo 12 günlük kitap okuma süresine göre öğretmen adaylarının BİT kullanmaya ilişkin yeterlilik algı ölçeğinden aldıkları puanlar arasında istatistiksel olarak anlamlı fark olduğunu göstermektedir $[\mathrm{F}(2-44)=4.07, \mathrm{P}<0.05]$. Görülen bu farklılı̆̆ın hangi gruplar 
arasında olduğunu belirlemek için gruplar birbiriyle karşılaştırılmıştır. Tukey testi sonuçlarına göre; günde 1 saatten az kitap okuyan öğretmen adayları $X=110.42$ ile 2-3 saat ve fazla kitap okuyan öğretmen adayları $X=127.44$ arasında 2-3 saat ve fazla kitap okuyanlar lehine; günde 1-2 saat kitap okuyan öğretmen adayları $X=112.08$ ile 2-3 saat ve fazla kitap okuyan öğretmen adayları $X=127.44$ arasında $2-3$ saat ve fazla kitap okuyanlar lehine anlamlı farklılıklar olduğu anlaşılmaktadır.

\section{Nitel Verilere İlișkin Bulgular}

Öğretmen adaylarının oluşturdukları blogların içerik analizi yöntemiyle analiz edilmesi sonucu elde edilen bulgulara yer verilmiştir.

1. Blog hazırlama deneyimi öncesinde ve hazırlama süresince BİT'e ilişkin yeterliliğinizi nasıl değerlendiriyorsunuz? sorusuna ilişkin tablo ve bulgular aşağıda yer almaktadır:

Tablo 13. Blog hazırlama deneyimi öncesinde ve hazırlama süresince BİT'e ilişkin yeterliliğinizi nasıl değerlendiriyorsunuz? sorusuna ilişkin frekans

Blog hazırlama deneyimi öncesinde ve hazırlama süresince $F$ BİT'e ilişkin yeterliliğinizi nasıl değerlendiriyorsunuz?

a) Yeterliydim ama blogla birlikte daha da geliştirdim. 18

b) Blog hazırlamadan önce yeterli değildim, çok fazla bir bilgim 24 yoktu. Blogtan sonra daha fazla bilgim oldu.

a) Yeterliydim ama blogla birlikte daha da geliştirdim diyen öğrencilerin frekansı 18 'dir. Bu öğrencilerin düşüncelerine yönelik örnekler şöyledir:

"Daha önce de blog hazırladığım için az çok bilgim vardı fakat bu blog ile birlikte daha da gelişti."Ö1

"Blog hazırlamaya başlamadan önce de gerekli yeterliliğe sahiptim fakat blog hazırlama sürecinde karşılaştığım bazı problemlerin çözümlerini aramam sonucunda yeni bilgiler öğrenerek yeterliliğimi daha da artırdı̆̆ımı düşünüyorum." Ö39

"Daha öncesinde de yeterliydim ama blog sonrası yeterliliğim arttı."Ö42

b) Blog hazırlamadan önce yeterli değildim, çok fazla bir bilgim yoktu. Blogdan sonra daha fazla bilgim oldu diyen öğrencilerin frekansı 24'tür. Bu öğrencilerin düşüncelerine yönelik örnekler şöyledir:

"Blog oluşturma konusunda bir fikrim yoktu. Ama bu çalışma sayesinde bir bloğum oldu." Ö11

"Blogu hazırlamaya başlarken ilk başlarda baya zorlandım. Daha sonra biraz kitabım hakkında araştırma yaptıktan sonra sandı̆̆ım kadar zorlanmayacă̆ımı düşünmeye başladım." Ö17

"Blog oluşturma konusunda hiçbir fikrim yoktu. Hatta kendimce ön yargılarım vardı. Ödev olarak verilen bu görevi nasıl yerine getireceğim hakkında tereddütlerim vardı. Ama başına geçince oluyor."Ö18

“Öncelikle blogger uygulamasinda ilk kez bir blog yazdım. Ama yazmadan önce bilgi toplama, veri analizi, uygulama kısmında da çok eğlendim. En azından dünyaca ünlü Nobel ve Pulitzer ödüllü kitap yazarı olan Steinbeck'in bir kitabını okuyup analiz etme 
firsatım oldu. Blogger da yazmış olduğum blog bilgi ve iletişim teknolojileri hakkında bildiklerimi uygulama firsatı verdi. Bunun yanında iletişim teknolojilerinin ayrıntılı araştırma yapabilme fırsatını da tanımış oldu." Ö22

"Illk blog hazırlamaya başlamadan önce bilgi ve iletişim teknolojileriyle aram hiç yoktu fakat şuan blog yapabilecek kadar bir şeyler öğrendim. Tam olarak yeterli sayılmasam da bir blog hazırlayabilirim." Ö34

"Blogu hazırlarken bilgi ve iletişim teknolojileriyle ilgili yeterliliğimin geliştiğini gördüm." Ö36

2. Blogunda kitaba yönelik fikirlerini paylaşmak sizi rahatsız etti mi? Yayınlanıyor olması düşüncesi kitaba yönelik yorumlarınızı etkiledi mi? Bu konudaki düşüncelerinizi açıklar mısınız? sorusuna yönelik olarak 45 öğrenci fikirlerini paylaşmaktan dolayı memnun olduklarını dile getirmiş; 1 öğrenci başkalarını olumsuz etkileyeceği kaygısından dolayı fikrini paylaşmaktan rahatsızlık duyduğunu dile getirmiştir. Bu öğrencilerin yorumlarına ilişkin örnekler ve tablo aşağıda yer almaktadır:

Tablo 14. Blogunda kitaba yönelik fikirlerini paylaşmak sizi rahatsız etti mi? Yayınlanıyor olması düşüncesi kitaba yönelik yorumlarınızı etkiledi mi? sorusuna ilişkin frekans

\begin{tabular}{|c|c|}
\hline $\begin{array}{l}\text { Blogunda kitaba yönelik fikirlerini paylaşmak sizi rahatsız } \\
\text { etti mi? Yayınlanıyor olması düşüncesi kitaba yönelik } \\
\text { yorumlarınızı etkiledi mi? Bu konudaki düşüncelerinizi } \\
\text { açıklar mısınız? }\end{array}$ & $F$ \\
\hline Hayır, rahatsız etmedi. & 45 \\
\hline Evet, rahatsız etti. & 1 \\
\hline
\end{tabular}

"Rahatsız etti çünkü beğenmediğim bir kitabı kesin bir dille beğenmedim deseydim okuyunca beğenecek olan arkadaşlarımı olumsuz etkileyecekti.." Ö4

"Hayır kesinlikle etkilemedi. Fikir ve düşüncelerimi özgürce ifade etmekten daha doğal bir şey olamaz herhalde. Bu yüzden çekinmedim veya fikirlerimi sakladı̆̆ım olmadı. Aklımdan geçeni düşündüğ̈̈̈m şeyleri yazdım elimden geldiğince. Daha tam tersine bütün ayrıntıları göz önüne sermeye çalıştım ki bloğa bakanlar bilgilensin diye" Ö16

"Hayır aksine çok iyi hissettirdi. Çünkü kendi fikirlerimin önemli olduğunu düşündüm. Kendimi bir blog yazarı olarak düşündüm. Arkadaşlarıma blog adresimi verdim, düşüncelerimi okusunlar diye. Bir günlük gibiydi." Ö19

"Bana ait olan bir sosyal medya hesabımda da okuduğum kitaplar hakkında fikirlerimi paylaştığım için bu durum beni rahatsız etmedi kesinlikle hatta daha şevkle yazdım yazdıklarımı eleştirel bakabildiğim için bir kitaba." Ö27

"Hayır rahatsız etmedi okuduğum kitap ile ilgili öğrendiklerim ve çıkarımlarımı tam tersi diğer insanlarla paylaşmak beni mutlu etti. Yayınlanıyor olması kitaba yönelik yorumlarım etkilemedi. Sadece biraz daha dikkatli ve titiz davranmaya çalıştım diyebilirim. Aldı̆̆ım her bilginin kaynă̆ına özellikle dikkat ettim ve özen gösterdim." Ö29

"Kesinlikle rahatsız etmedi. Tam tersine daha çok rahatlattı diyebilirim. Insanlarla bilgi paylaşımında bulunmak harika bir duygu. Yayınlanıyor olması kitaba yönelik yorumlarım kesinlikle etkilemedi. Herkes farklı düşüncelerde olabilir. Bu paylaştığım 
makalelerde de görülmektedir. Önemli olan insanları bu kitabı okumaya teşvik edip kitap, yazar ve dönem hakkında bilgi vermektir." Ö42

3. Çalışma iki aşamadan oluştu. İlk aşamada verilen kitaplar okundu sonrasında kitaba ilişkin eleştiriler blogda yayınlandı. Çalışmanın ilk aşamasının mı, ikinci aşamasının mı zevkli olduğunu düşünüyorsunuz? Nedenlerini açıklar mısınız? sorusuna yönelik olarak 12 öğrenci kitap okuma, 26 öğrenci blog oluşturma aşamasının, 6 öğrenci de her iki aşamasının da zevkli olduğunu ifade etmişlerdir. Bu öğrencilerin yorumlarına ilişkin örnekler ve tablo aşağıda yer almaktadır:

Tablo 15. Çalışmanın ilk aşamasının $\mathrm{ml}$, ikinci aşamasının $\mathrm{m}$ zevkli olduğunu düşünüyorsunuz? sorusuna ilişkin frekans

\section{Çalışma iki aşamadan oluştu. İlk aşamada verilen kitaplar $F$ okundu sonrasında kitaba ilişkin eleştiriler blogda yayınlandı. Çalışmanın ilk aşamasının mı, ikinci aşamasının mı zevkli olduğunu düşünüyorsunuz? Nedenlerini açıklar misiniz?}

\begin{tabular}{ll}
\hline a) Birinci aşama yani kitap okuma aşaması daha zevkliydi. & 12 \\
\hline b) İkinci aşama yani blog oluşturma daha zevkliydi. & 26 \\
\hline c) Her iki aşamanın da kendine göre güzellikleri vardı. & 6
\end{tabular}

a) Birinci aşama yani kitap okuma aşaması daha zevkliydi diyen öğrencilerin frekansı 12 'dir. Bu öğrencilerin düşüncelerine yönelik örnekler şöyledir:

\footnotetext{
"Kitap okuma kısmı çünkü kitabı kafandaki gibi bloğa geçiremiyorsun." Ö4

"Illk aşaması daha zevkliydi. Çünkü kitap okumak daha zevkli." Ö9

“ilk aşaması daha zevkliydi. Çünkü bilgisayarla uğraşmayı pek sevmiyorum."Ö15

“Çalışmanın ilk aşaması daha zevkliydi. Hem kitabı okuduk hem üzerinde düşündük. Ayrıca araştırmalar yaptık, kitapla ve o dönemle ilgili bir sürü bilgiyi öğrenmiş olduk."Ö38

"Aslında her iki aşaması da güzeldi yani her ikisi de farklı benim için ancak çalışmanın ilk aşaması benim için daha keyifliydi. Kitabı okumak büyük bir zevkti çünkü kitabı çok beğgendim."Ö29,
}

b) İkinci aşama yani blog oluşturma daha zevkliydi diyen öğrenci frekansı $26^{\prime}$ dır. Öğrencilerin yorumlarından örnekler şunlardır:

\footnotetext{
"İkinci aşama daha zevkliydi çünkü bloguma yazılarımı yazarken araştırmalar yaptım ve bu sayede bilmediğim birçok şey öğrendim. Çalışmanın ikinci aşaması daha zevkliydi çünkü bloğumuzu tasarlamak olsun orada resimler paylaşmak olsun çok zevkliydi. Bir de blogta her paylaşımımdan sonra istatistiklere bakıp bugün bloğumu 60 kişinin ziyaret ettiğini görünce mutlu oluyordum." Ö2

"İkinci aşama daha keyifliydi. İnternet ortamında yazılar hazırlamak gayet zevkli oldu." Ö6

“İkinci aşama daha zevkliydi çünkü okuduğum kitabın üzerine farklı bakış açıları edinecek yazılar okudum. Olayların tarihi gerçekliğin bir yansıması olduğunu fark ettim. Zweig'ın derin yaşantısının sembolü olan kitapla tarih izlere tanık oldum."Ö10
} 
"İkinci aşama daha zevkliydi çünkü kendimizden bir şeyler katıp daha sonrasında çeşitli kitap ve makalelerden yararlandık bunları sentezleyip yeni bir paragraf oluşturabildik. Bu açıdan ikinci aşama birinci aşamaya istinaden daha zevkliydi."Ö11

“İkinci aşamanın daha zevkli olduğunu düşünüyorum. Çünkü başta sadece kitabı okudum. Ama blogda paylaşmaya başlayınca her ince ayrıntısına kadar kitabı incelediğimi fark ettim." Ö12

"İkinci aşaması daha zevkliydi çünkü yeni bir bilgiyi öğrenmenin heyecanı vardı." Ö13

"İkinci aşamanın daha zevkli olduğunu düşünüyorum. Kitap eleştirisi yapmak kitabın iyi ve kötü yönlerini göz önüne koymak daha zevkli geldi bana. Kitaptaki güzel sözleri bulmak ilişkileri en ince ayrıntısına kadar değerlendirmek eğlenceliydi." Ö16

"Ben en çok ikinci aşamayı beğendim. Çünkü kendi fikirlerimi, kitabın bende oluşturduğu etkiyi birileriyle paylaşmak çok güzel bir duygu. Kimse karışmadan fikirlerimi rahat bir şekilde yazabiliyorum. Eleştirel bakıyorsun artık her kitaba."Ö19

"Ben blog hazırlamayı daha çok sevdim. Biraz vakit alabiliyor evet ama kitap hakkında tarama yaparken yazar ve kitap hakkında birçok bilgiye ulaşmak kitabı sevmemi sağladı. Bir şeyler hazırlayıp sonucunu herkese göstermek tebrik yorumları almakta ayrı hoşuma gitti. Illeride öğrencilerim için bu blogu kullanabilirim diye düşünüyorum."Ö20

"Kesinlikle çalışmanın ikinci aşamasının daha zevkli olduğunu düşünüyorum. Illk aşamada zevk aldı̆̆ğm iki nokta oldu. Birincisi yeni bir kitap okuyor olmamd, ikincisi de kitabı okurken inceleme yapacă̆ımı bildiğim için ayrıntılara özen göstererek okumak oldu. Lakin çalışmanın ikinci aşaması beni daha çok kendine çekti. Çünkü şahsım adına, araştırmayı seven bir yapım var. Fareler ve Insanlar'ı analiz ederken kitap, bilgisayar, makalelerle baş başa kaldım ve bu çalışma harareti beni mutlu etti. O yüzden çalışmanın ikinci aşaması daha verimli geçti benim için."Ö23

“Çalışmanın ikinci aşaması daha zevkliydi. Kitapta geçen dönemin şartları ilgimi çekti bu konuda araştırma yapmak ve eleştirmek daha güzeldi."Ö30

"Çalışmanın ikinci aşamasında daha zeok aldım çünkü kitabı daha iyi analiz etmemi să̆ladt."Ö35

"Blog hazırlama süreci beni daha çok etkiledi çünkü okuduğum ve bilgim bir konu hakkında yazı yazmak beni daha çok heyecanlandırdı. Yazarın kitapta bahsettiğ $i$ karakterleri gözümde canlandı ̆̆ı şekilde bloğa koymak, karakterler hakkında bilgi vermek daha eğlenceliydi."Ö39

"Elbette ki ikinci aşaması daha zevkliydi benim için. Çünkü ilk aşamada pasif durumdaydım. İkinci aşamada ise söz konusu çalışmada daha aktif rol aldım. Bu da ikinci aşamanın benim için daha zevkli geçmesini să̆ladı."Ö40

“Çalışmanın ikinci aşaması daha zevkliydi. Çünkü kitabı bitirip eleştiriler yazmak ve kitapla ilgili birçok kaynaktan makalelerden, kitaplardan bilgiler toplamak çok zevkliydi. Bunları insanlarla paylaşmak ve yararlı olduğunu bilmek ayrica gurur verici bir durum. Bloğuma başka kitaplarla devam etmek istiyorum."Ö42

"Ben ikinci aşamasının zevkli olduğunu düşünüyorum. Çünkü yapılan çeşitli çalışmalarm sonucunda ortaya bir ürün çıkarmak son derece zevk veren bir duygu. Insansın yaptı̆̆g iş sonucunda yorumlar alması, çalışmalarının beğenilmesi mutluluk veren bir duygu."Ö45 
"İkisi de güzeldi. Ama bir şeyleri ortaya koymak elbette daha baskın çıkacaktır. O yüzden blog oluşturma kısmını daha çok sevdim."Ö46

c) Her iki aşamasını da zevkli buldum diyen öğrenci frekansı 6' dır:

"Her iki çalışmanın da kendine göre zevkli kısımları vardı."Ö17.

\section{SONUÇ}

Günümüz eğitim öğretim ortamlarında bilginin aktarılmasından ziyade öğrencilerin bilgiye ulaşmalarında ve elde ettikleri bilgiyi yapılandırmalarında öğretmenlerin rehberliği önem kazanmıştır. Buna yönelik gelişen teknoloji ile birlikte eğitim öğretim ortamları geleneksel yöntemlerden uzaklaşarak öğrencilerin ihtiyaçlarına göre yeniden düzenlenmesini, ders tasarımlarının bu teknolojilerin işe koşularak yapılmasını gerekli kılmaktadır. Bu anlamda çalışmada da uygulaması gerçekleştirilen bloglar, derslerde etkili ve verimli öğrenme ortamlarının geliştirilmesi için önem arz etmektedir. Bloglar yardımıyla öğretmen adayları çevrim içi platformda teknoloji ile iç içe, paylaşıma açık, fikir alışverişi içerisinde oldukları çok yönlü etkileşimin, aynı zamanda kendilerinin aktif konumda olduğu bir yapıda eleştirel bir bakış açısıyla okudukları eserlere yönelik fikirlerini yapılandırmışlardır. Çalışmada cevap aranan problemlere ilişkin edilen sonuçlar şöyledir:

1. Öğretmen adaylarının eleştirel okuma öz yeterlilik algıları "yeterli" düzeydedir.

2. Günlük 2-3 saat ve fazla kitap okuyan öğretmen adaylarının eleştirel okuma yeterlilik algısı günlük 1 saat ve daha az ile 1-2 saat kitap okuyanlara göre anlamlı derecede yüksek bulunmuştur.

3. Öğretmen adaylarının eleştirel okuma öz yeterlilik algısının günlük kitap okuma süresine göre dağılımına yönelik, günlük BİT kullanım süresine göre eleştirel okuma öz yeterlilik algısı ölçme aracından aldıkları puanların ortalamaları arasında istatistiksel olarak anlamlı bir fark bulunmamıştır.

4. Öğretmen adaylarının BİT kullanmaya ilişkin ölçeğin genelinden alınan puanların ortalaması "Yeterliyim" aralığına denk gelmektedir.

5. Öğretmen adaylarının BİT kullanmaya ilişkin yeterlilik algılarının günlük BíT kullanım süresine göre dağılımına ilişkin, günlük BİT kullanım süresine göre BİT yeterlilik algı ölçme aracından aldıkları puanların ortalamaları arasında istatistiksel olarak anlamlı bir fark olmadığı bulunmuştur.

6. Öğretmen adaylarının BİT kullanmaya ilişkin yeterlilik algısının günlük kitap okuma süresine göre dağılımı günlük 2-3 saat ve fazla kitap okuyan öğretmen adaylarının BİT yeterlilik algısı 1 saat ve 1-2 saat daha az okuyanlara göre anlamlı bulunmuştur.

7. Öğretmen adaylarının BİT yeterlilik algılarına ilişkin blog hazırladıktan sonra BİT yeterliliklerinin geliştiğini gördüklerini, yaptıkça öğrendiklerini dolayısıyla artık kendi başlarına bir blog hazırlayabileceklerini, dile getirmişlerdir.

8. Hazırladıkları blogda kitaba yönelik fikirleri paylaşmaya ilişkin öğretmen adaylarının düşünceleri, öğrencilerin okuduğu esere yönelik eleştirel okumayı gerçekleştirip anlayıp, yorumlayarak yayımlamayı bu bilgileri çevrim içi ortamda paylaşmayı istemekte olduğu yönündedir. Öğrencilerin, birbirlerinin bloglarında yaptığı yorumların özellikle okumak isteyip sürekli ertelenen kitaplar konusunda teşvik edici olduğu yönündedir. Aynı eseri ele alan öğrencilerin yaptıkları fikir 
alışverişi de onlara hem farklı bir bakış açısı sunmuş hem de fikir alışverişi yapma imkânı sağlamıştır.

9. Kitap okuma ve blog hazırlama süreçlerinin öğretmen adayları için zevkli olan aşamasına ilişkin düşünceleri; öğretmen adayları blogda yayın yapmayı zevkli bulmaktadır. Dolayısıyla bloglar eğitim öğretime uygulanabilen yapısıyla bilgi paylaşımını da desteklemektedir.

Alan yazında blog uygulaması yoluyla gerçekleştirilen çalışmalara bakıldığında genel olarak İngilizce öğrenenlere yönelik araştırmalarda blog uygulamalarının gerçekleştirildiği görülmüştür. Örneğin Koçoğlu (2009) ve Ruby (2011) tarafından yapılan çalışmaların sonuçları blog uygulamasının İngilizce öğrenen öğrencilerin yazma becerilerini geliştirdiği yönündedir. Bloglara yönelik araştırmalarda blogların, yabancı dil sınıflarında ve çoğunlukla yazma becerisine yönelik (Akdağ ve Özkan, 2017; Alsamadani, 2018; Armstrong ve Retterer, 2008; Arslan ve Şahin-Kızıl, 2010) ele alındığı söylenebilir. Okuma becerisine yönelik Türker ve Genç (2018), tarafından gerçekleştirilen yabancı dil olarak Türkçe öğretiminde blog kullanımının okuma becerisine etkisine yönelik başka bir araştırmada, bu çalışmanın bulgularına paralel olarak öğrencilerin bloglara yönelik tutumları ile okuma başarıları arasında pozitif yönlü anlamlı bir ilişki olduğu sonucu elde edilmiştir.

Öğretmen adaylarının okudukları esere yönelik blog oluşturma, düşüncelerini aktarma çabalarının, eleştirel okumaya olduğu kadar yazma becerilerine yönelik öz yeterliklerini de geliştirdiği düşünülmektedir. Bu bağlamda, çalışmadan elde edilen bulgulardan hareketle önerilebilecek olan, eğitimin her kademesinde Web 2.0 araçlarının kullanılarak başka uygulamalı çalışmaların gerçekleştirilmesi yönündedir.

\section{SUMMARY}

Aim:

This research aims to determine the self-competence levels of pre-service teachers regarding the use of information and communication technologies (ICT) and critical reading.

\section{Methodology:}

Both quantitative and qualitative methods were used in the research. The concurrent triangulation strategy was used as the design of mixed research.

The research was conducted using the data collected from the third-year students of the Turkish Language Teaching Undergraduate Program who took the World Literature course in the fall semester of 2018-2019.

In the study, pre-service teachers were asked to read one of the classics of world literature and to prepare a blog about the study they read. The teacher candidates formed their views related to the books they read with a critical viewpoint.

\section{Results and conclusion:}

As a result of the application and research that lasted for 14 weeks, teacher candidates' self-competence levels regarding ICT use and critical reading were determined as "sufficient" according to the scale used in the research.

The scores of the pre-service teachers who read at least 2-3 hours a day from the "critical reading self-efficacy scale" and "ICT efficacy scale" differed significantly. 
It was observed that the findings obtained from the qualitative data and the findings obtained from the quantitative data were consistent.

It was observed that the pre-service teachers enjoyed publishing and sharing their thoughts on the blog.

The writing skills of the preservice teachers improved after their blog preparing experience.

It is recommended that pre-service teachers have hands-on experience using Web 2.0 tools during their undergraduate education.

\section{Makale Bilgileri}

$\begin{array}{ll}\text { Etik Kurul Kararı: } & \text { Kütahya Dumlupınar Üniversitesi Sosyal ve Beşeri Bilimler Bilimsel } \\ & \text { Araştırma ve Yayın Etiği Kurulu Kararı (Onay numarası: E.16365 } \\ & \text { /21.05.2020 ) } \\ & \text { Gönüllülük esas alınmıştır. } \\ \text { Katılımcı Rızası: } & \text { Çalışma için herhangi bir kurum ve projeden mali destek } \\ \text { Mali Destek: } & \text { alınmamıştır. } \\ \text { Çalışmada kişiler ve kurumlar arası çıkar çatışması } & \text { bulunmamaktıdır. } \\ \text { Çalışmada kullanılan görsellerle ilgili telif hakkı sahiplerinden } \\ \text { gelif Hakları: }\end{array}$

Article Information

Ethics Committee Approval: The study received Ethical Approval from Kütahya Dumlupınar University, Social and Human Sciences Scientific Research and Publication Ethics Committee (Approval number: E.16365 /21.05.2020)

Informed Consent: Voluntarily participation.

Financial Support: The study received no financial support from any institution or project.

Conflict of Interest: The authors declare any conflict of interest.

Copyrights:

The required permissions have been obtained from the copyright holders for the images and photos used in the study. 


\section{KAYNAKÇA}

Akbayır, S. (2013). Eğitim fakülteleri için cümle ve metin bilgisi. Ankara: Pegem Akademi.

Akdağ, E. \& Özkan, Y. (2017). enhancing writing skills of efl learners through Blogging. The Reading Matrix: An International Online Journal, 17(2), 79-95.

Akyol, H. (2011). Türkçe öğretim yöntemleri. Ankara: Pegem Akademi Yayıncıllk.

Alsamadani, H-A. (2018). The Effectiveness of Using Online Blogging for Students' Individual and Group Writing. International Education Studies, 11(1), 44-51.

Armstrong, K., \& Retterer, O. (2008). Blogging as L2 writing: A case study. AACE Journal, 16(3), 233-251.

Aslan, R.Ş. \& Şahin-Kızıl, A. 2010. How can the use of blog software facilitate the writing process of English language learners?. Computer Assisted Language Learning, 23: 183-197.

Aydin, S. \& Özdemir, E. (2020). Using blogs to motivate english as a foreign language writers. Recent Developments in Technology-Enhanced and Computer Assisted Language Learning. 257-278. doi: 10.4018/978-1-7998-1282-1.ch012

Baltacı, A. (2017). Nitel veri analizinde miles-huberman Modeli. Ahi Evran Üniversitesi Sosyal Bilimler Enstitüsü Dergisi, 3 (1), 1-15.

Creswell, J. W. (2003). Research design: Qualitative, quantitative, and mixed methods approaches (2nd ed.). Thousand Oaks, CA: Sage

Çifçi, M. (2006). Eleştirel okuma. Belleten, 1, 55-80.

Daskalogiannaki, E. D. (2012). Developing and assessing EFL students' writing skills via a classblog. Research Papers In Language Teaching E Learning, 3(1), 269-292.

Demir, R. \& Kan, M.O. (2017). 7. Sınıf öğrencilerinin eleştirel okuma becerileri. Mersin Üniversitesi Ĕ̆itim Fakültesi Dergisi, 13(2), 666-682.

Erden, M. (1998). Eğitimde program değerlendirme. Ankara: Anı Yayıncılık.

Fraenkel, J. R., Wallen, N. E. \& Hyun, H. H. (2015). How to design and evaluate research in education (9. ed.). New York: Mc Graw Hill Companies.

Göktaş, Y. (2009). Incorporating blogs and the seven principles of good practice into preservice 1ct courses: A case study. The New Educational Review, 19, 3-4.

Hsin-Yi Cyndi, H. (2016). Students and the Teacher's Perceptions on Incorporating the Blog Task and Peer Feedback into EFL Writing Classes through Blogs. English Language Teaching, 9(11), 38-47.

https://link.springer.com/chapter/10.1007/978-3-319-07482-5_10

Hui-Ju, Lu. (2011). Learners' perceptions on the use of blogs for efl learning. online submission, US-China Education Review. 3, 323-330.

Kaptan, S. (1998). Bilimsel araştırma ve istatistik teknikleri. Ankara: Tekışık Matbaası.

Karabay, A. (2012). Eleştirel okuma-yazma eğitiminin türkçe öğretmeni adaylarının akademik başarılarına ve eleştirel okuma yazma düzeylerine etkisi. Yayınlanmamış Doktora Tezi. Çukurova Üniversitesi Eğitim Bilimleri Enstitüsü, Adana, Türkiye.

Karadeniz, A. (2014). Eleştirel okuma öz-yeterlik algısı ölçeğinin geçerlilik ve güvenirlik çalışması. Bartın Üniversitesi Ĕ̆itim Fakültesi Dergisi, 3 (1), 113-140.

Koçoğlu, Z. (2009). Weblog use in EFL writing class. Ankara University Journal of Faculty of Educational Sciences, 42(1), 311-327. 
MEB (2011). Öğretmen Yeterlikleri: Öğretmenlik Mesleği Genel ve Özel Alan Yeterlikleri. Ankara: Millî Eğitim Bakanlığı Yayınları.

MEB. (2019). Illköğretim Türkçe dersi öğretim programı (1-8. Sinıflar). Ankara: MEB.

Nicolaou, A., \& Constantinou, E. K. (2014). Blogging revisited: the use of blogs in ESAP courses. International Conference on Learning and Collaboration Technologies, 95-106. Cham: Springer

Noytim, U. (2010). Weblogs enhancing EFL students' English language learning. Procedia Social and Behavioral Sciences, 2(2), 1127-1132.

Özdemir, E. (2015). Blog Kullanımının yabancı dil olarak ingilizce öğrenenlerin yazma motivasyonu üzerine etkileri. Yayınlanmamış Yüksek Lisans Tezi. Balıkesir Üniversitesi Sosyal Bilimler Enstitüsü, Balıkesir, Türkiye.

Richardson, W. (2010). Blogs, wikis, podcasts and other powerful web tools for classrooms. Thousand Oaks, CA: Corwin Press.

Ruby, V. (2011). Enhancing writing skills through blogs in an EFL Class. European association for computer-assisted language learning (EUROCALL), European Association for Computer-Assisted Language Learning (EUROCALL) Annual Conference, Nottingham, United Kingdom, Aug 31-Sep 3.

Şad, S.N. ve Nalçacı, Ö.İ. (2015). Öğretmen adaylarının eğitimde bilgi ve iletişim teknolojilerini kullanmaya ilişkin yeterlilik algıları. Mersin Üniversitesi Ĕ̆itim Fakültesi Dergisi, 11(1), 177-197.

Türker, M. S. ve Genç, A. (2018). Yabancı dil olarak Türkçe öğretiminde blogların öğretim amaçlı kullanımı üzerine öğrenci ve öğretmen görüşleri. Selçuk Üniversitesi Edebiyat Fakültesi Dergisi, 39, 251-266.

Yıldırım, A. ve Şimşek, H. (2006). Sosyal Bilimlerde Nitel Araştırma Yöntemleri, Ankara: Seçkin Yayınevi.

Yıldız, M., \& Akyol, H. (2011). İlköğretim 5. sınıf öğrencilerinin okuduğunu anlama, okuma motivasyonu ve okuma alışkanlıkları arasındaki ilişki. Gazi Üniversitesi Gazi Eğitim Fakültesi Dergisi, 31(3), 793-815. 


\section{EKLER}

Ek 1. Dünya Edebiyatı Dersi Kapsamında Öğretmen Adaylarının Okudukları Kitapların Listesi

\begin{tabular}{|c|c|}
\hline Kategori & Kitap Ad1 \\
\hline İtalyan & Cesare Pavese (Ay ve Şenlik Ateşleri) \\
\hline Rus & F. M. Dostoyevski (Karamazov Kardeşler) \\
\hline Rus & İ.S. Turgenyev (Babalar ve Oğullar) \\
\hline Rus & M. Gorki (Ana) \\
\hline Rus & N.V.Gogol (Ölü Canlar) \\
\hline Rus & Puşkin (Yüzbaşının Kızı) \\
\hline Rus & L.N. Tolstoy (İvan İlyiç'in Ölümü) \\
\hline Fransiz & Victor Hugo (Sefiller) \\
\hline Fransiz & H. Balzac (Vadideki Zambak) \\
\hline Fransiz & Gustav Flaubert (Madam Bovary) \\
\hline Fransiz & M.H. B. Stendhal (Kırmızı ve Siyah) \\
\hline Kirg1z & Cengiz Aytmatov (Cemile) \\
\hline Çek/Avusturya & Stefan Zweig (Satranç) \\
\hline İran & Sâdık Hidâyet (Kör Baykuş) \\
\hline Alman & Knut Hamsun (Açlık ) \\
\hline Alman & J. W. V. Goethe (Genç Werther'in Acıları) \\
\hline $\mathrm{ABD}$ & Çanlar Kimin İçin Çalıyor (Ernest Hemingway) \\
\hline $\mathrm{ABD}$ & John Steinbeck (Fareler ve İnsanlar) \\
\hline $\mathrm{ABD}$ & William Faulkner (Ses ve Öfke) \\
\hline $\mathrm{ABD}$ & Jack London (Martin Eden) \\
\hline İngiliz & Charles Dickens (İki Şehrin Hikâyesi) \\
\hline İngiliz & Jane Austen (Gurur ve Önyarg1) \\
\hline Balkan/Romanya & Panait Istrati (Akdeniz) \\
\hline Yugoslav & Mehmet (Meşa) Selimoviç (Derviş ve Ölüm) \\
\hline Yugoslav & Drina Köprüsü (İvo Andriç) \\
\hline Hint & Gora (Rabindranath Tagore) \\
\hline İtalyan & Cesare Pavese (Ay ve Şenlik Ateşleri) \\
\hline Fransiz & Victor Hugo (Sefiller) \\
\hline Rus & İ. S. Turgenyev (Babalar ve Oğullar) \\
\hline Rus & M. Gorki (Ana) \\
\hline Rus & N.V. Gogol (Ölü Canlar) \\
\hline Rus & Puşkin (Yüzbaşının Kızı) \\
\hline Rus & F. M. Dostoyevski (Karamazov Kardeşler) \\
\hline Rus & L. N. Tolstoy (İvan İlyiç' in Ölümü) \\
\hline Fransiz & H. Balzac (Vadideki Zambak) \\
\hline Fransiz & Gustav Flaubert (Madam Bovar) \\
\hline Fransiz & M.H. B. Stendhal (Kırmızı ve Siyah) \\
\hline Kirg1z & Cengiz Aytmatov (Cemile) \\
\hline Çek/Avusturya & Stefan Zweig (Satranç) \\
\hline İran & Sâdık Hidâyet (Kör Baykuş) \\
\hline Alman & Açlık (Knut Hamsun) \\
\hline $\mathrm{ABD}$ & Çanlar Kimin İçin Çalıyor (Ernest Hemingway)) \\
\hline
\end{tabular}




\begin{tabular}{ll}
\hline ABD & John Steinbeck (Fareler ve İnsanlar) \\
ABD & William Faulkner (Ses ve Öfke) \\
ABD & Jack London (Martin Eden) \\
İngiliz & Charles Dickens (İki Şehrin Hikâyesi \\
İngiliz & Jane Austen (Gurur ve Önyargi) \\
Balkan/Romanya & Akdeniz (Panait Istrati) \\
Yugoslav & Mehmet (Meşa) Selimoviç (Derviş ve Ölüm) \\
Yugoslav & Drina Köprüsü (İvo Andriç) \\
Hint & Gora (Rabindranath Tagore) \\
\hline
\end{tabular}

Ek 2. Öğretmen Adaylarının Hazırladıkları/Yayımladıkları Blog Sayfa Örnekleri

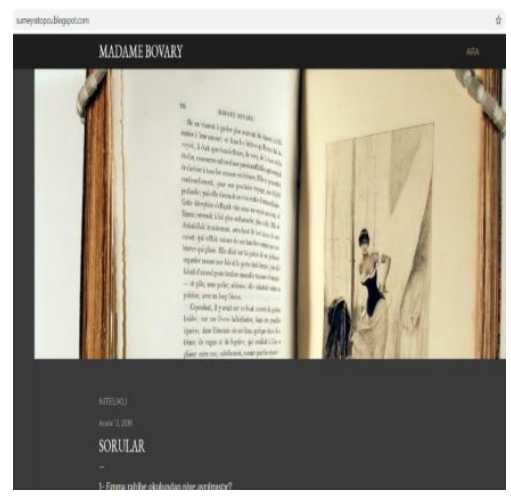

http://sumeyratopcu.blogspot.com/

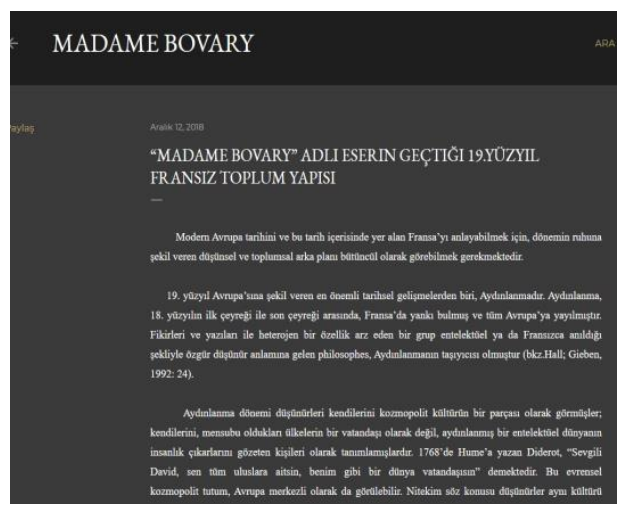

http://sumeyratopcu.blogspot.com/

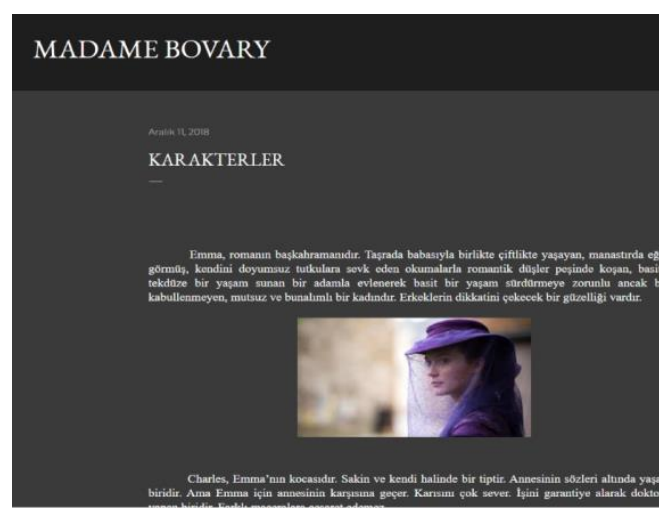

http://sumeyratopcu.blogspot.com/
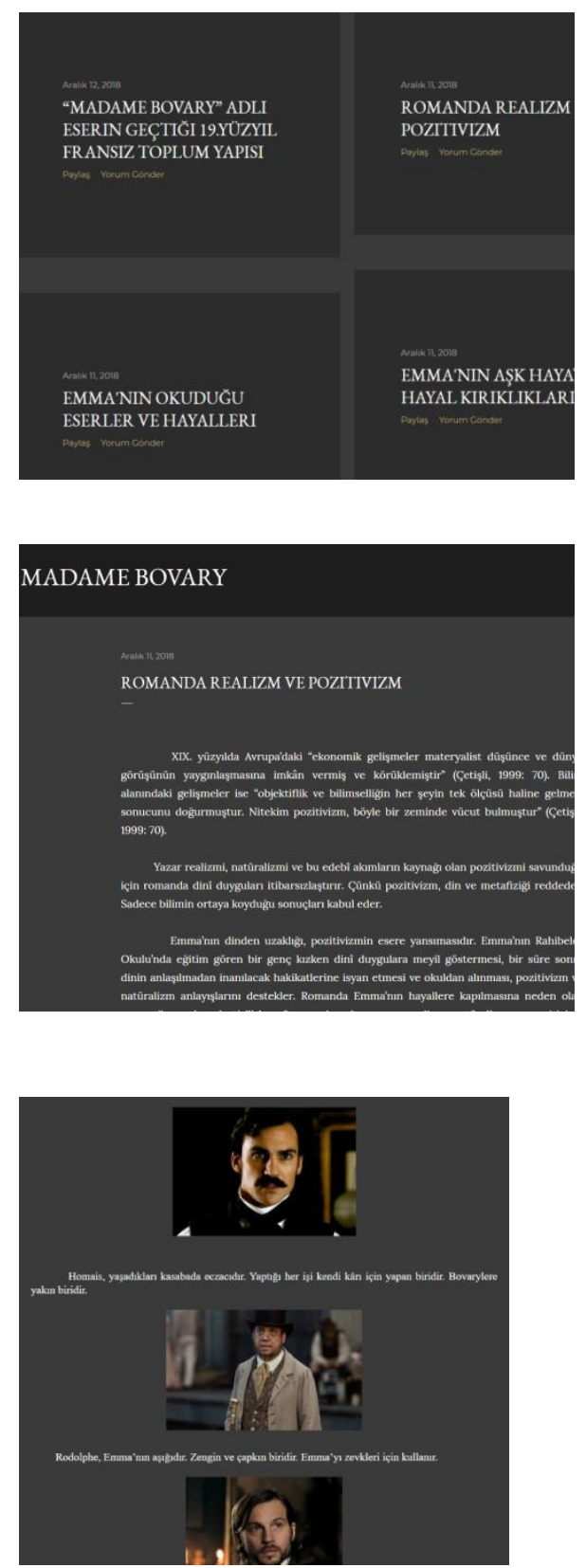


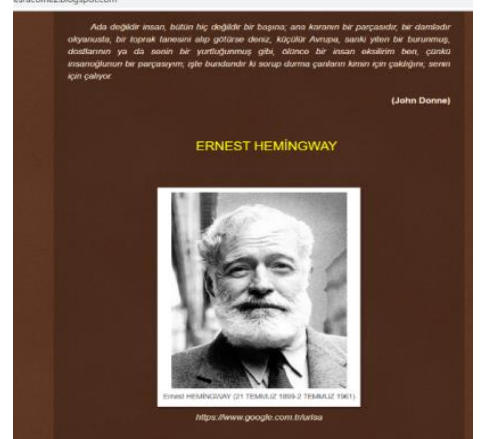

http://esracomez.blogspot.com/

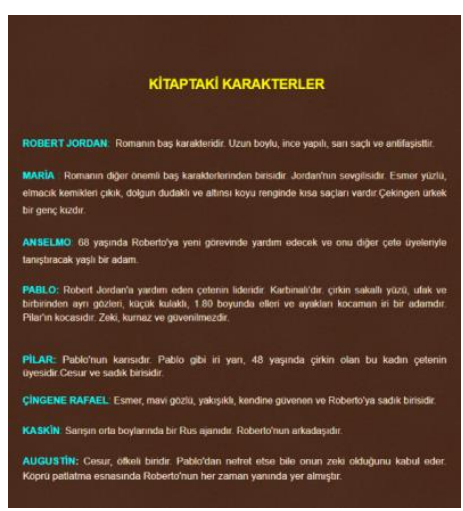

http://esracomez.blogspot.com/

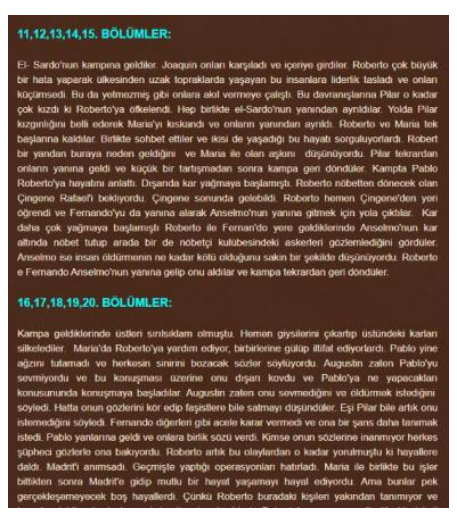

http://esracomez.blogspot.com/

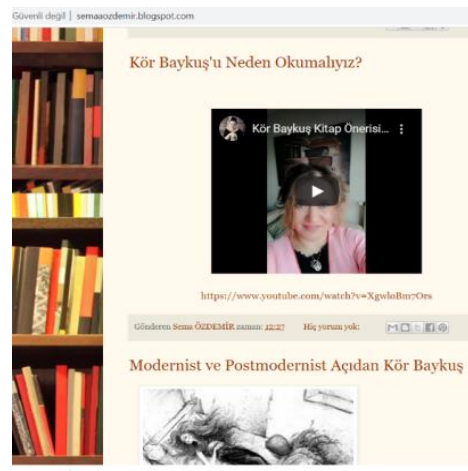

http://semaaozdemir.blogspot.com/
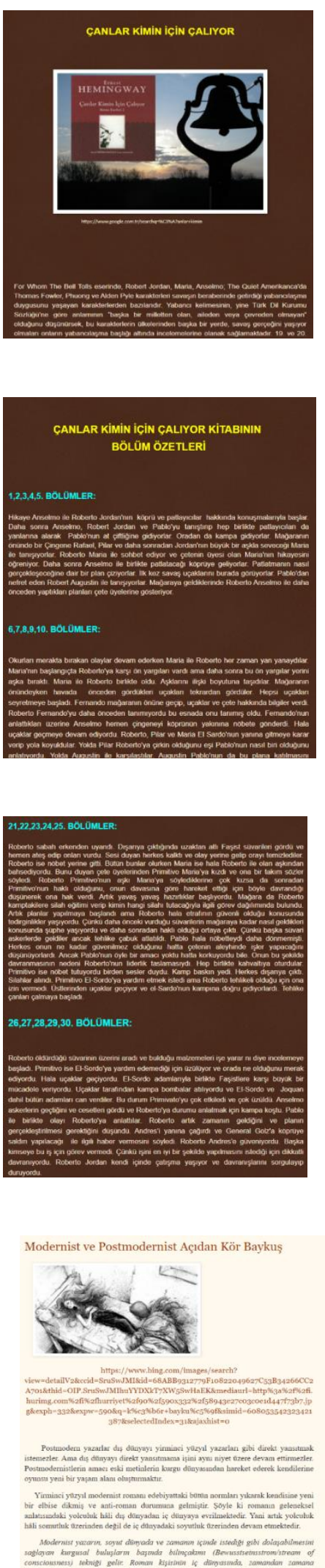


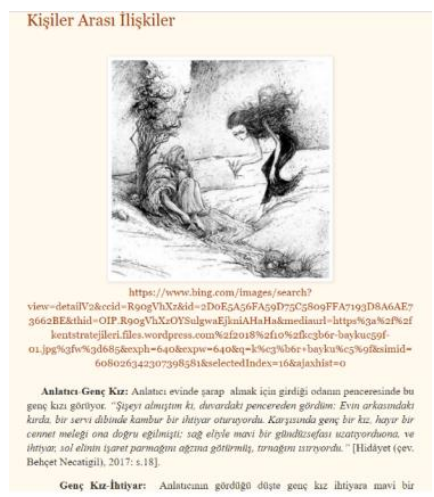

http://semaaozdemir.blogspot.com/

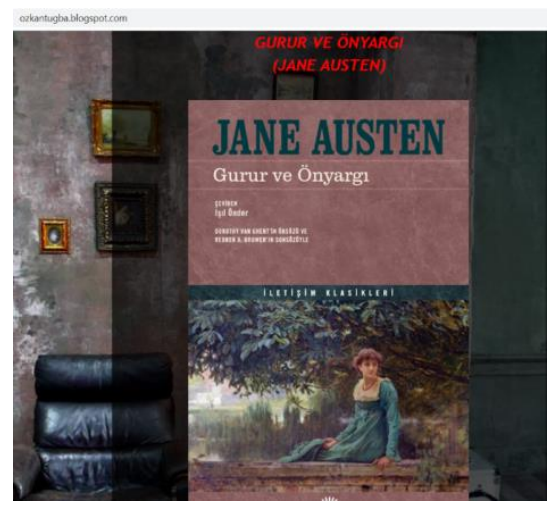

https://ozkantugba.blogspot.com/

akdenizromaniblogspotcom

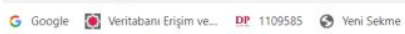

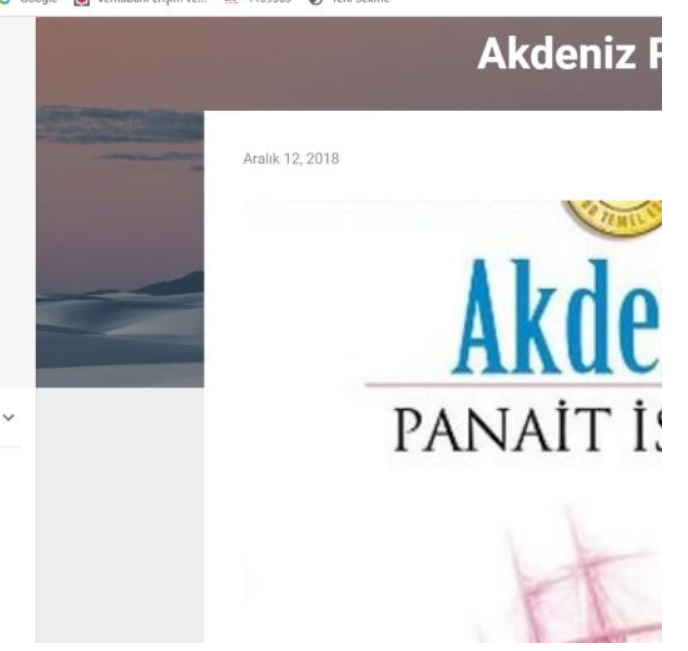

http://akdenizromani.blogspot.com/
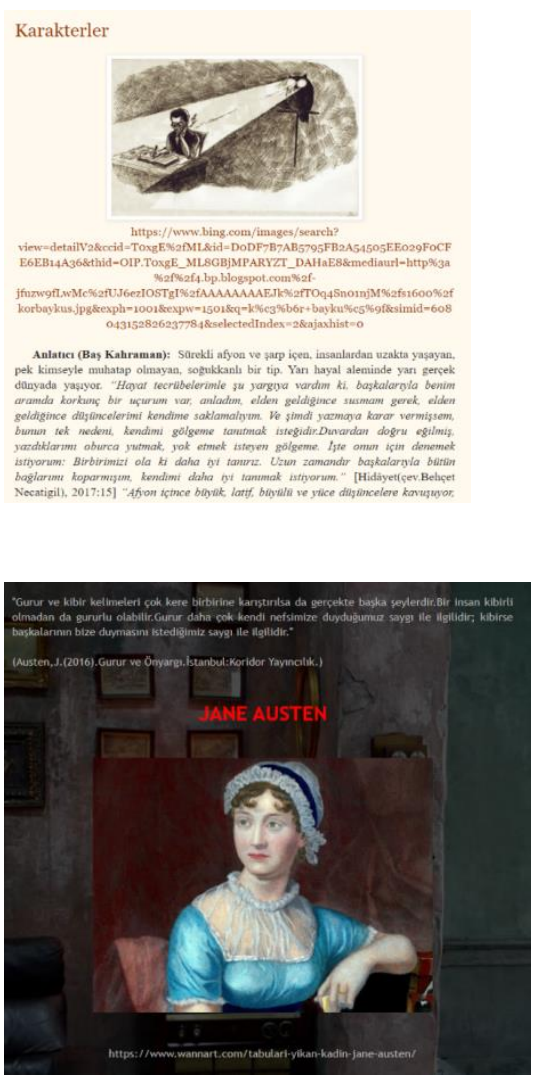

Akdeniz Romanı

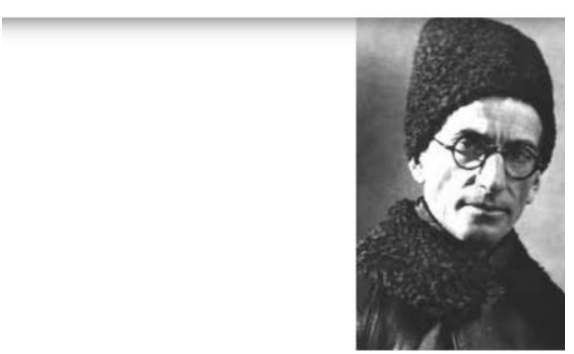

Romanyảnn bir liman kenti olan lbrail'de 1884 yilında doğmuștur. Balka Rum kaçakçı Gerasim Valsamis ile çamaşırı Romen Yoitza Istratínin e Panait doğduktan bir yil sonra öldürülmüştür. Annesiyle birlikte yoksullư altında bitirmiştir. Serbest hayatta tezgâhtarlik da dâhil olmak üzere sey hayatla âdeta pençeleșerek mücadele etmiştir. 
metehanozcelik.blogspot.com

G Google Veritabanı Erișim ve... DP 1109585 Yeni Sekme

Stefan Zweig' in Hayatı
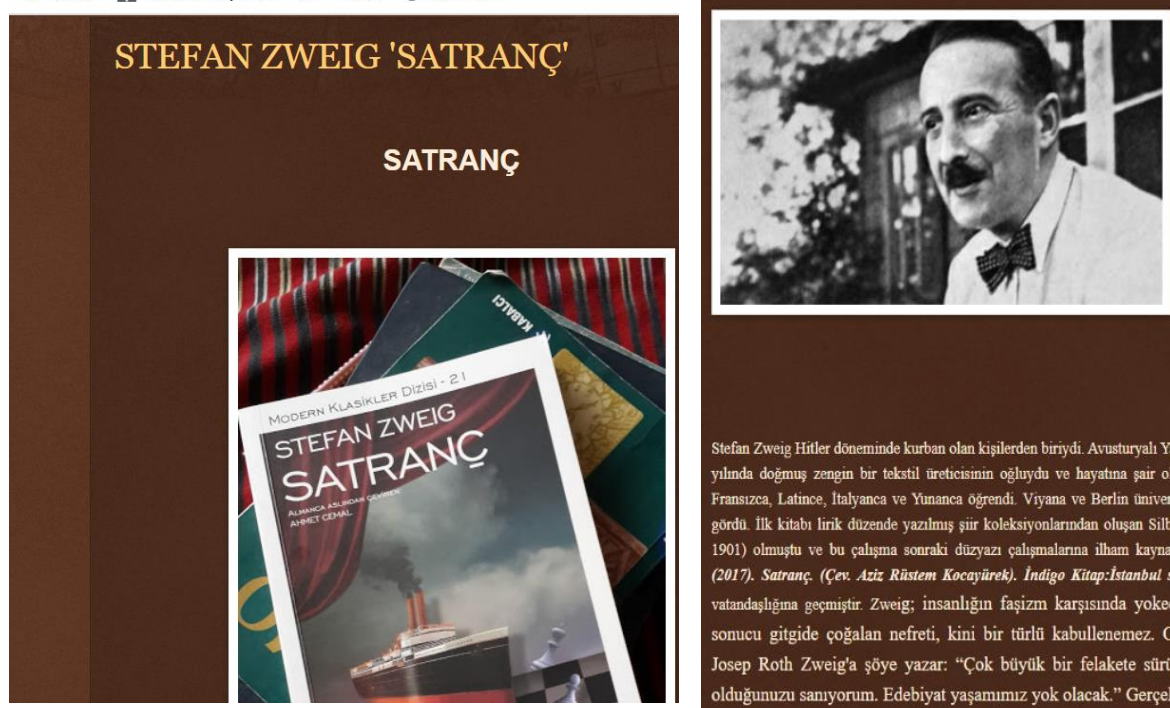

http://metehanozcelik.blogspot.com/ 